\title{
The pharmacological and therapeutic importance of Eucalyptus species grown in Iraq
}

\author{
Prof Dr Ali Esmail Al-Snafi \\ Department of Pharmacology, College of Medicine, Thi qar University, Iraq
}

\begin{abstract}
Eucalyptus species grown in Iraq were included Eucalyptus bicolor (Syn: Eucalyptus largiflorens), Eucalyptus griffithsii, Eucalyptus camaldulensis (Syn: Eucalyptus rostrata) Eucalyptus incrassate, Eucalyptus torquata and Eucalyptus microtheca (Syn: Eucalyptus coolabahs). Eucalypts contained volatile oils which occurred in many parts of the plant, depending on the species, but in the leaves that oils were most plentiful. The main constituent of the volatile oil derived from fresh leaves of Eucalyptus species was 1,8-cineole. The reported content of 1,8-cineole varies for 54-95\%. The most common constituents co-occurring with 1,8cineole were limonene, $\alpha$-terpineol, monoterpenes, sesquiterpenes, globulol and $\alpha, \beta$ and $\Upsilon$-eudesmol, and aromatic constituents. The pharmacological studies revealed that Eucalypts possessed gastrointestinal, antiinflammatory, analgesic, antidiabetic, antioxidant, anticancer, antimicrobial, antiparasitic, insecticidal, repellent, oral and dental, dermatological, nasal and many other effects. The current review highlights the chemical constituents and pharmacological and therapeutic activities of Eucalyptus species grown in Iraq.
\end{abstract}

Keywords: Eucalyptus species, constituents, pharmacological, therapeutic

\section{INTRODUCTION:}

In the last few decades there has been an exponential growth in the field of herbal medicine. It is getting popularized in developing and developed countries owing to its natural origin and lesser side effects. Plants are a valuable source of a wide range of secondary metabolites, which are used as pharmaceuticals, agrochemicals, flavours, fragrances, colours, biopesticides and food additives [1-50]. Eucalyptus species grown in Iraq were included Eucalyptus bicolor (Syn: Eucalyptus largiflorens), Eucalyptus griffithsii, Eucalyptus camaldulensis (Syn: Eucalyptus rostrata) Eucalyptus incrassate, Eucalyptus torquata and Eucalyptus microtheca (Syn: Eucalyptus coolabahs)[51-54]. Eucalypts contained volatile oils which occurred in many parts of the plant, depending on the species, but in the leaves that oils were most plentiful. The main constituent of the volatile oil derived from fresh leaves of Eucalyptus species was 1,8-cineole. The reported content of 1,8cineole varies for 54-95\%. The most common constituents co-occurring with 1,8-cineole were limonene, $\alpha$ terpineol, monoterpenes, sesquiterpenes, globulol and $\alpha, \beta$ and $\Upsilon$-eudesmol, and aromatic constituents. The pharmacological studies revealed that Eucalypts possessed gastrointestinal, antiinflammatory, analgesic, antidiabetic, antioxidant, anticancer, antimicrobial, antiparasitic, insecticidal, repellent, oral and dental, dermatological, nasal and many other effects. The current review will highlight the chemical constituents and pharmacological and therapeutic activities of Eucalyptus species grown in Iraq.

\section{Synonyms}

Eucalyptus bicolor:Eucalyptus largiflorens F. Muell., Eucalyptus parviflora F. Muell. and Eucalyptus pendula [55].

Eucalyptus camaldulensis: Eucalyptus acuminata Hook, Eucalyptus canalouensis Dehnh, Eucalyptus rostrata Schltdl, Eucalyptus longirostris F. Muell. ex Miq, Eucalyptus subulata A. Gray, Eucalyptus camaldulensis subsp. camaldulensis, Eucalyptus camaldulensis subsp. obtusa (Blakely) Brooker \& M.W. McDonald, Eucalyptus camaldulensis var. acuminata (Hook.) Blakely, Eucalyptus camaldulensis var. brevirostris (F. Muell. ex Miq.) Blakely, Eucalyptus camaldulensis var. camaldulensis, Eucalyptus camaldulensis var. obtusa Blakely, Eucalyptus camaldulensis var. pendula Blakely \& Jacobs, Eucalyptus camaldulensis var. subcinerea Blakely, Eucalyptus longirostris f. brevirostris F.Muell. ex Miq, Eucalyptus longirostris forma longirostris Miq; Eucalyptus rostrata var. acuminata (Hook.) Maiden, Eucalyptus rostrata var. borealis R. T. Baker \& H. G. Sm; Eucalyptus rostrata var. brevirostris Maiden and Eucalyptus tereticornis var. rostrata (Schldl.) Ewart [56].

Eucalyptus griffithsii: Eucalyptus griffithsii var. angustiuscula [57]. 
Eucalyptus incrassata: Eucalyptus costata F. Muell., Eucalyptus costata subsp. murrayana L A S Johnson \& K D Hill, Eucalyptus incrassata subsp costata F Muell and Eucalyptus incrassata subsp. costata (F Muell) F C Johnstone \& Hallam [58].

Eucalyptus microtheca: Eucalyptus coolabah and Eucalyptus raveretiana var. jerichoensis [59-60].

Eucalyptus rostrata: It is one of the synonyms of Eucalyptus camaldulensis [61].

Taxonomic classification:

Kingdom: Plantae, Subkingdom: Viridiplantae, Infrakingdom: Streptophyta, Superdivision: Embryophyta, Division: Tracheophyta, Subdivision: Spermatophytina, Class: Magnoliopsida, Superorder: Rosanae, Order: Myrtales, Family: Myrtaceae, Genus: Eucalyptus [62].

\section{COMMON NAMES}

Eucalyptus bicolor: Arabic: kalebtoz, kalmtoz; English: red box, goborro.

Eucalyptus camaldulensis (syn: Eucalyptus rostrata): Afrikaans: rooibloekom; Arabic: eucalyptus, eucalyptus kamali, Kaffour, kena; Chinese:chi an; English: blue gum, Murray red gum, red gum, red river gum, river gum, river red gum; French: eucalyptus rouge; German: roter Eukalyptus; Indonesian: ekaliptus; Italian: eucalipto rostrato; Spanish: eucalipto-negro, eucalipto-rojo; Swedish: röd eucalyptus [63].

Eucalyptus griffithsii: English: grey gum, Griffith's grey gum [64].

Eucalyptus incrassata: English: lerp mallee, mallee-box, ridge-fruit mallee, yellow mallee [64].

Eucalyptus microtheca ( Syn: Eucalyptus coolabahs): English: coolabahs, coolibah, flooded-box, western coolibah $[60,63]$.

Eucalyptus torquata: Arabic: Kalptos, English: christmas tree, coolgardie gum, coolgardie-rose, coral gum, coral-flower gum, goldfields red-flower gum, pink-flower gum [65].

\section{DISTRIBUTION}

Eucalyptus is a large genus indigenous to Australia, Tasmania, New Guinea and the neighboring islands, where they constitute a large portion of the forest vegetation and giving it a characteristic appearance. Now Eucalyptus genus is found in almost all parts of the world due to human introduction, particularly in subtropical and warm temperate regions [63-64, 66-67].

\section{Eucalyptus bicolor:}

\section{DESCRIPTION}

Tree to $20 \mathrm{~m}$ high; bark persistent, grey to grey black, fibrous-flaky (box), throughout. Juvenile leaves disjunct, linear, dull grey-green to glaucous. Adult leaves disjunct, narrow-lanceolate to lanceolate, 9-18 cm long, 0.8-1.8 cm wide, grey-green, dull, concolorous. Conflorescence compound; umbellasters 7-11-flowered; peduncle terete, 3-11 mm long; pedicels terete, 1-5 mm long. Buds ovoid, 4-5 mm long, 2-3 mm diam., scar present; calyptra hemispherical or conical, shorter and narrower than hypanthium. All stamens fertile. Fruit hemispherical or ovoid-truncate, 3-6 mm long, 3-5 mm diam.; disc depressed; valves enclosed or rim-level [6869].

\section{Eucalyptus camaldulensis:}

Eucalyptus camaldulensis commonly grows to $20 \mathrm{~m}$ tall, occasionally reaching $50 \mathrm{~m}$, with a trunk diameter of $1(\max .2) \mathrm{m}$; in open formations has a short, thick bole and a large, spreading crown; in plantations has a clear bole of $20 \mathrm{~m}$ with an erect, lightly branched crown; bark smooth, white, grey, yellow-green, greygreen or pinkish grey, shedding in strips or irregular flakes; rough bark occupies the 1st 1-2 m of the trunk. Leaves grey-blue, alternate, drooping, 8-22 cm long, 1-2 cm wide, often curved or sickle shaped, tapering, short pointed at base. Inflorescence axillary, solitary, 7-11 flowered; flower buds white, globularrostrate or ovoidconical; operculum hemispherical, rostrate or conical, 4-6 x 3-6 mm, obtuse. Fruit very small capsules at the end of thin stalks, 5-8 mm, valves 4, containing minute seeds [70-71].

\section{Eucalyptus griffithsii:}

Bark: smooth throughout, white or grey or red-brown. Leaves: Intermediate leaves disjunct early, lanceolate to ovate, straight, entire, dull grey green, petiolate. Adult leaves disjunct, lanceolate, falcate, acute, basally tapered, glossy, green or grey-green, thick, concolorous; Petioles narrowly flattened or channelled. Lateral veins obscure, acute. Inflorescences: Conflorescence simple, axillary; Umbellasters 3-flowered. Peduncles narrowly flattened or angular (to $3 \mathrm{~mm}$ wide). Flowers: Buds clavate, not glaucous or pruinose. Calyx calyptrate; shedding early. Calyptra hemispherical, 1 times as long as hypanthium, wider than hypanthium; 
corrugated. Hypanthium ribbed. Flowers white. Fruits: campanulate. Disc depressed. Valves exserted. Chaff dimorphic, linear and cuboid [72-73].

\section{Eucalyptus incrassata:}

Bark: smooth throughout, grey or grey-brown, shedding in long ribbons. Branchlets green. Leaves: Intermediate leaves disjunct early, elliptic to ovate, straight, entire, dull grey green to dull green, petiolate, $10 \mathrm{~cm}$ long, $5 \mathrm{~mm}$ wide. Adult leaves disjunct, lanceolate or broad lanceolate, not falcate, obtuse or apiculate, basally tapered, glossy or semi-glossy, grey-green, thick, concolorous, 6-11 cm long, 1.5-2.5 mm wide; Petioles narrowly flattened or channelled, Petioles 10-20 mm long. Lateral veins obscure, acute, moderately spaced. Inflorescences: Conflorescence simple, axillary; Umbellasters 3-flowered to 7-flowered, regular. Peduncles narrowly flattened or angular (to $3 \mathrm{~mm}$ wide), $13-20 \mathrm{~mm}$ long. Pedicels terete, 3-5 mm long. Flowers: Buds cylindrical or fusiform, not glaucous or pruinose, 12-20 mm long, 6-8 mm diam. Calyx calyptrate; shedding early. Calyptra conical (often beaked), 2 times as long as hypanthium or 3 times as long as hypanthium, as wide as hypanthium; smooth, or ribbed. Hypanthium smooth, or ribbed. Flowers cream. Fruits: cylindrical or urceolate (slightly), pedicellate, 3-4 locular, 8-13 mm long, 7-11 mm diam. Disc depressed. Valves enclosed. Chaff dimorphic, linear and cuboid, chaff same colour as seed [74-75].

\section{Eucalyptus microtheca ( Syn: Eucalyptus coolabah)}

Bark: persistent throughout, fibrous-flaky with whitish patches (box), grey or grey-black, grey. Leaves: Intermediate leaves disjunct early, lanceolate to ovate, straight, entire, dull grey green, petiolate. Adult leaves disjunct, narrow lanceolate to broad lanceolate, not falcate, acute, basally tapered, dull, grey-green, thin, concolorous. Lateral veins obscure, acute. Inflorescences: Conflorescence compound, terminal or axillary; Umbellasters 3-flowered to 7-flowered. Peduncles terete. Flowers: Buds ovoid or obovoid, not glaucous or pruinose. Calyx calyptrate; shedding early. Calyptra hemispherical and rostrate, 1 times as long as hypanthium or 2 times as long as hypanthium, as wide as hypanthium; smooth. Hypanthium smooth. Flowers white, or cream. Fruits: hemispherical. Disc flat. Valves rim-level or exserted. Chaff dimorphic, linear and cuboid [7677].

\section{Eucalyptus torquata:}

Eucalyptus torquata is a small to medium-sized, spreading tree from 4 to 10 metres high with rough, persistent bark on the trunk and often also on the larger branches. The leaves are lanceolate, $90-120 \mathrm{~mm}$ long by 15-20 mm wide and greyish green in colour. The flower buds are distinctive, having a rough, corrugated base to both the bud itself and the cap (operculum), which tapers to a long point. The flowers are large (up to $35 \mathrm{~mm}$ in diameter) and normally coral-pink but white, cream and red flowered plants are known [78].

\section{Traditional uses:}

The oil was used traditionally for the treatment of cystitis, diabetes, gastritis, kidney disease, laryngitis, leukorrhoea, malaria, pimples, ringworm, wounds, ulcers of the skin, urethritis and vaginitis. It was also used as an expectorant for symptomatic treatment of mild inflammation of the respiratory tract, bronchitis, asthma, and inflammation of the throat [79-81]. In south Europe, oil was used for fever, neuralgic pain, asthma, lung tuberculosis and as an antiseptic agent [82]. It is used externally for wounds, acne, poorly healed ulcers, stomatitis, bleeding gums, rheumatism and neuralgia [83]. However, There were three broad categories of uses for Eucalyptus oil (medicinal, industrial and perfumery/flavouring) [84].

\section{Medicinal parts:}

The oil extracted from the fresh and dried leaves and branch tips were used medicinally [85].

\section{Chemical constituents:}

Eucalypts contained volatile oils which occurred in many parts of the plant, depending on the species, but in the leaves that oils were most plentiful. Eucalyptus oil was produced and stored in small glands, the leaves of different species contained from $0.1-7 \%$ of the fresh weight of the leaves [84].The main constituent of the volatile oil derived from fresh leaves of Eucalyptus species was 1,8-cineole. The reported content of 1,8cineole varies for 54-95\%. 1,8-cineole showed a great variations along the seasons, but mature leaves always have higher contents of 1,8-cineole. Beside 1,8-cineole, the oil contained monoterpenes such as cymene, $\alpha$ pinene, $\beta$-pinene and limonene, geraniol and camphene. Aromadendrene, cuminaldehyde, globulol and pinocarveol were also isolated from the Eucalyptus oil [79, 86-90]. The most common constituents cooccurring with 1,8-cineole were limonene, $\alpha$-terpineol (both of which can be derived from the menth-1-en-8-yl cation, the same 
biogenetic precursor from which cineole is thought to be derived), monoterpenes (such as $\alpha$-pinene), sesquiterpenes (such as aromadendrene), globulol and $\alpha, \beta$ and $\Upsilon$-eudesmol, and aromatic constituents (such as methyl cinnamate) [91-93].Beside the oil, the genus Eucalyptus also contained complex mixtures of plant secondary metabolites, including terpenoids, cyanogenic glycosides, hydrolysable and condensed tannins, flavonoids, long chain ketones, and formylated phloroglucinol compounds [94]. Twenty-six compounds were isolated from the oil of Eucalyptus bicolor (Syn: Eucalyptus largiflorens) with 1,8-cineole (37.5\%), p-cymene $(17.4 \%)$ and neoisoverbenol $(9.1 \%)$ as main components [95].The preliminary phytochemical analysis of different parts of Eucalyptus camaldulensis revealed that the plant contained alkaloids, flavonoids, terpenoids, tannins, saponins, glycosides, steroids and anthraquinones [96].The constituents of the essential oil of Eucalyptus camaldulensis were predominately oxygenated monoterpenes (34.9\%), followed by oxygenated sesquiterpenes (31.8\%), monoterpene hydrocarbons (29.0\%) and sesquiterpene hydrocarbons (4.3\%) [97]. Essential oil from aerial parts of Eucalyptus camaldulensis growing wild in different localities of SardiniaItaly, was extracted by steam distillation and analyzed by gas chromatography, FID and GC-ion trap mass spectrometry. The yields of essential oil (v/dry wt) ranged between $0.2-0.5 \%$. Thirty-seven compounds, accounting for at least $97.7 \%$ of the total essential oils were identified, the major components being p-cymene (27.8-42.7\%), 1,8-cineole (4.1-39.5\%), beta-phellandrene (3.9-23.8\%), spathulenol (2.1-15.5\%) and cryptone (3.2-10.2\%). The oils showed moderate amounts (1.4-4.7\%) of two uncommon aldehydes, cuminal and phellandral [98].

Analysis of the Eucalyptus camaldulensis leaves essential oil revealed the presence of 24 and 27 compounds from the saline and non saline samples, respectively. The constituents of the essential oil from saline and non saline samples (\%)resspectively were: $\alpha$-Pinene $14.68 \pm 0.42$ and $12.43 \pm 0.37$, Camphene 0.87 \pm 0.07 and $2.96 \pm 0.12, \beta$-Pinene $6.66 \pm 0.17$ and $2.33 \pm 0.19$, Eucalyptol $34.42 \pm 1.21$ and $40.05 \pm 1.20, \Upsilon$ Terpinene $9.42 \pm 0.36$ and $7.48 \pm 0.29, \delta$-Terpinene $1.11 \pm 0.06$ and $1.17 \pm 0.05, \alpha$-Iinene epoxide $0.27 \pm 0.02$ and $0.28 \pm 0.02$, Isoamyl isovalerate $1.07 \pm 0.09$ and $1.10 \pm 0.07$, Fenchyl alcohol $0.79 \pm 0.03$ and $0.89 \pm$ $0.05, \alpha$-Camphdenic Aldehyde $0.66 \pm 0.03$ and $0.67 \pm 0.02, \quad t$-Pinocarveol $8.36 \pm 0.40$ and $3.32 \pm 0.11$, Myrtenal $0.94 \pm 0.03$ and $0.97 \pm 0.06$, Z-Carveol $1.15 \pm 0.04$ and $1.25 \pm 0.07, d$-Carvone $0.51 \pm 0.03$ and $0.36 \pm 0.02, o$-Cymene 5-ol $0.46 \pm 0.03$ and $0.54 \pm 0.02$, Benzyl valerate - and $0.14 \pm 0.01, \alpha$-Gurjunene and $0.26 \pm 0.02$, b-gurjunene - and $0.22 \pm 0.03$, Aromadendrene $2.63 \pm 0.16$ and $2.78 \pm 0.20$, Alloaromadendrene $0.89 \pm 0.05$ and $0.97 \pm 0.07$, Phenethyl Isovalerate $0.90 \pm 0.03$ and $1.01 \pm 0.06$, Ledene $0.45 \pm 0.05$ and $0.52 \pm 0.03$, Epiglobulol $1.83 \pm 0.09$ and $1.96 \pm 0.03$, Ledol $7.42 \pm 0.05$ and $7.67 \pm 0.08$, Viridiflorol $1.13 \pm 0.04$ and $2.76 \pm 0.06$, Eremophilene $0.78 \pm 0.03$ and $0.85 \pm 0.02$ and g-Cadinene $0.29 \pm$ 0.01 and $0.33 \pm 0.02$ [99]. The physicochemical characteristics of Eucalyptus camaldulensis leaves essential oil, saline and non saline samples were (respectively): oil content (\% fresh matter basis) $0.98 \pm 0.10$ and 0.96 \pm 0.120 .83 ; refractive index $\left(40{ }^{\circ} \mathrm{C}\right) 1.4620 \pm 0.01$ and $1.4580 \pm 0.020 .77$; solubility $(\mathrm{ml} / 5 \mathrm{ml}$ of $70 \%$ ethanol) $0.93 \pm 0.10$ and $1.05 \pm 0.160 .33$; density $\left(25^{\circ} \mathrm{C}\right) 0.938 \pm 0.04$ and $0.936 \pm 0.040 .95$; specific gravity $\left(25^{\circ} \mathrm{C}\right)$ $0.920 \pm 0.04$ and $0.919 \pm 0.040 .97$; physical appearance: colorless- dark yellow [99]. New triterpenoid acids (eucalyptanoic acid) was isolated from the fresh uncrushed leaves of Eucalyptus

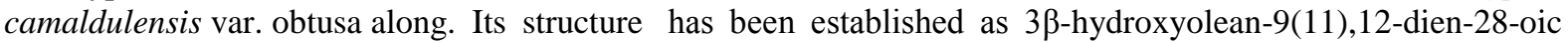

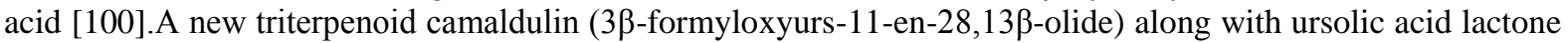
acetate, ursolic acid lactone, betulinic acid and $\beta$-sitosterol 3-O- $\beta$-d-glucopyranoside were isolated from Eucalyptus camaldulensis var. obtuse leaves [101]. Triterpenoid amirinic acid (2alpha,3beta,7beta-trihydroxy11 alpha-methoxyurs -12-en-28-oic acid and 2alpha, 3beta, 7beta-trihydroxyurs-11-en-28,13beta -olide), ursolic acid lactone, betulinic acid, oleanolic acid and ursolic acid, were isolated from fresh, uncrushed leaves of Ecalyptus camaldulensis var. obtuse [102]. Total penolics in the Eucalyptus camaldulensis leaves was $364.1 \pm$ 8.2 (mg gallic acid equivalent/ g) and total flavonoids was $80.5 \pm 0.9$ (mg quercetin equivalent/ g) Eucalyptus camaldulensis leaves contained many phenolic groups and compounds including ellagitannins, flavonoids, phloroglucinol derivatives and galloyl esters [103]. Eucalyptus incrassata leave sample yielded 2\% w/w (dry leaves ) of essential oils [104]. 1,8-cineole (30\%), $\alpha$-pinene (18\%), aromadendrene (13\%) were the main constituents of Eucalyptus incrassate leaves essential oils, however, the oils of Eucalyptus incrassata contained: 1,8-cineole; Allo-aromadendrene; Alpha-bulnesene; Alpha-campholenic-aldehyde; Alpha-copaene; Alpha-cubebene; Alpha-eudesmol; Alpha-fenchene; Alpha-gurjunene; Alpha-phellandrene; Alpha-pinene; Alpha-selinene; Alpha-terpineol; Aromadendrene; Beta-caryophyllene; Beta-cis-ocimene; Beta-cubebene; Betaelemene; Beta-eudesmol; Beta-phellandrene; Beta-pinene; Beta-selinene; Beta-trans-ocimene; Bicycloelemene; Bicyclogermacrene; Cadina-1,4-diene; Calacorene; Calamenene; Caryophyllene-oxide; Cis-p-menth-1,8-dien6-ol; Cryptone Leaf; Delta-cadinene; Delta-elemene; Fenchol; Gamma-eudesmol; Gamma-terpinene; Geraniol; Globulol; Isoamyl-isovalerate; Isobutyl-isovalerate; Limonene; Myrcene; P-cymen-8-ol; P-cymene; Palustrol; Pinocarvone; Sabinene; Spathulenol; Terpinolene; Torquatone; Trans-p-menth-1,8-dien-6-ol; Transp-menth-2-en-1-ol; Trans-p-mentha-1(7),8-dien-2-ol; Trans-pinocarveol, Trans-piperitol, Viridiflorene and Viridiflorol [105-106]. 
New euglobals, euglobal-In-1, euglobal-In-2, euglobal-III and euglobal -V having an acylphloroglucinolsesquiterpene structure were isolated from the juvenile leaves of Eucalyptus incrassate [107].

The total amount of the oil in the leaves of the Eucalyptus griffithsii was $0.3 \%$ of the dry weight. The main constituents of the Eucalyptus griffithsii leaves essential oils were 1,8-cineole (26\%), trans pinocarveol (11\%) and $\alpha$-pinene (8\%) [105]. The Phytochemical analysis of Eucalyptus microtheca leaves extracts revealed the presence of essential oils, flavonoids, tannins and alkaloids [108]. The major components of Eucalyptus microtheca essential oils were 1,8-cineole (34.0\%), p-cymene $(12.4 \%), \alpha$-pinene $(10.7 \%), \beta$ - pinene $(10.5 \%)$ and virdiflorene (5.2\%) [95].However, in the oil of Eucalyptus microtheca flowers, 88 compounds were identified including (\%): $\alpha$-thujene $0.504 ; \alpha$-pinene $16.246 ; \alpha$-fenchene 0.078; Comphene 0.271; Verbenene $0.051 ; \beta$ - pinene $11.082 ; \beta$-myrcene $\quad 0.263 ; \alpha$-phellandrene $7.006 ; \alpha$-terpinene 0.367 ; 0 cymene 13.522; Sabinene2.131; Limonene 2.713; cis-ocimene 0.149; $\gamma$-terpinene 0.868; Isopropenyltoluenecymene 0.093; $\alpha$-terpinolene 0.189; Linalool L 0.058; Appel oil 0.113; D-fenchyl alcohol 0.085; Hexadecane0.147; Trans-pinocarveol 0.365; Pinocarvone 0.303; 4-methyl-1,3-heptadiene (c,t) 0.088; 2, 4-hexadiene, 2, 5-dimethyl- 0.070; 4-terpineol 1.052; Myrtenal 0.202; $\alpha$-terpineol0.425; Myrtenol 0.160 ; Dodecane 0.392; $\beta$-citronellol 0.365; Piperitone 0.167; Citrol 0.063; Citronellyl formate 0.115; Diglycol dimethacrylate 0.787; Carvacrol 0.494; 2-butylpyridine 0.129; soledene 0.170; Copaene 0.150; Tetradecane $0.063 ; \quad \beta$-elemene 0.063; $\alpha$-gurjunene 0.542; Seychelene0.040; Trans-Caryophyllene 0.227; $\gamma-$ selinene 0.122; Calarene 0.112; $\beta$ - gurjunene 0.073; Aromadendrene 7.444; $\alpha$-humulene 0.080; Alloarmadendrene1.632; $\alpha$-amorphene $\quad 0.400 ; \quad \beta$-selinene $0.311 ; \quad \alpha \quad$-guaiene $\quad 0.320$; Ledene2.135; $\alpha$-muurolene $0.318 ; \gamma$-cadinene 0.667; Calamenene0.248; $\delta$-cadinene1.040; Cadina-1, 4-diene 0.045; $\alpha$-calacorene 0.070; Epiglobulol 0.975; $\beta$-maaliene 0.253; Plustrol 0.221; Spathlenol1.848; Globulol 5.419; Veridiflorol 1.044; Ledol 0.631; Hexadecane 0.212; $\alpha$-ylangene 0.196; Isospathulenol 0.217 ; Tau-cadinol 0.791; $\quad \alpha$-cadinol 0.444; Cadalene 0.120; N-octadecane 0.246; Tetradecanamide 0.321; n-hexadecanoic acid 0.375; Ecosane 0.167; Hexaadecanamide0.918; Octadecanoic acid 0.425; Docosan 0.145; 9-octadecenamide 5.414; Di-[2-ethylhexyl] phthalate 0.584 ; 4- methylenespiro $[2,4]$ heptane 0.055; (2-methylprop-1-enyl)-cyclohexa- 1, 3-diene $\quad 0.098 ; \quad$ 1-(2'-hydroxy-3',4'-dimethylphenyl) ethanone0.603; Trans-1,6-dimethyl bicycle (4.3.0) non-2-en-7-one $\quad 0.346 ; \quad 7, \quad 9$-di-tert-butyl-1-oxaspiro [4.5] deca-6, 9- diene-2, 8-dione0.117; 1, 3- cyclohexadiene, 2-methyl-5-(1-methylethyl), monoepoxide

0.139 and 1H-cyclopropa[e]azulene, decahydro-1, 1, 7-trimethyl-4-methylene-,[1aR (1a.1alpha. 4a.beta. 7b.alpha)] - 7.alpha, 7a.beta 0.243. While, in the essential oil of Eucalyptus microtheca leaves, 101 compounds were identified included (\%): $\alpha$-thujene $0.742 ; \alpha$-pinene 6.752 ; comphene $0.079 ; \beta$ - pinene 5.006; $\beta$ myrcene $0.533 ; \alpha$-phellandrene $16.487 ; \alpha$-terpinene 0.832 ; p- cymene $5.251 ; \beta$-phellandrene 2.194; Limonene 1.503; Cis-ocimene 1.655; $\beta$-ocimene Y 0.101; $\gamma$-terpinene 1.235; Cymene 0.024; $\alpha$-terpinolene 0.425; Rosefuran 0.024; Cycloheptanmethanol 0.061; Linalool L 0.093; Isoamyl isovalerate 0.529; Isoamyl valerate 0.056; Fenchol 0.076; Trans-pinene hydrate 0.062; Allocimene 0.049; 1-terpineol 0.045; 1methylnorcarane 0.051; Ethylbenzoate 0.124; 4-terpineol1.256; 1 -(adamantly) cyclohexene $0.042 ; \beta$-fenchol 0.203; cis-sabinol 0.224; Thiophene, 2-ethyl-5-methyl $0.120 ;$ Ascaridole 0.085; Dicyclobutylidene oxide 0.084; Divinyl dimethylsilane $\quad 0.114$; Piperitone 0.196; 1-methoxyhept-1-yne 1.809; Citronellyl formate 0.029; Carvacrol 0.420; $\alpha$-cubebene 0.160; Isoledene 0.278; Copaene 0.308; 2-pentene-1-ol, 2-methyl $0.215 ; \quad \alpha$-gurjunene 1.897; Trans-caryophyllene 0.539; Aromadendrene 12.773; Epizonaren 0.067; $\alpha-$ humulene 0.142; Alloarmadendrene $2.520 ; \gamma$-gurjunene $0.327 ; \alpha$-copaene $0.755 ; \beta$-selinene $0.525 ; \beta$ panasinsene 0.702; Ledene $\quad 5.665 ; \alpha$-muurolene 0.398 ; Geremacrene B 0.099; $\alpha$-amorphene 1.666; cis-calamenene $0.207 ; \delta$-cadinene 2.663 ; Cadina-1, 4-diene $0.103 ; \alpha$-calacorene $0.087 ; \quad \alpha-$ cadinene 0.163; Ledane 0.092; Epiglobulol 1.167; $\beta$-maaliene 0.306; Palustrol 0.190; Spathlenol 1.915; Globulol 5.997; Veridiflorol 1.243; 1, 3-dimethyl-5-ethyladamantane 0.285; Ledol 0.753; $\gamma$ - curcumene 0.391; Isospathulenol 0.300; Tau-muurolol 1.580; $\delta$-cadinol 0.231; Guaia-3, 9-diene 0.292; $\alpha$ - cadinol 0.806; Vulgarol A 0.129; Hexadecanoic acid 0.093; 2-tridecanol 0.028; Hexadecanoic acid ethyl ester 0.025; Decyltetraglycol 0.025 ; Tricosane 0.012 ; Benzonitrile, m-phenethyl 0.032 ; Pentacosane 0.073; Pentaethoxylated pentadecyl alcohol $\quad 0.036 ; \quad$ 1-cyclohexene-1-carboxaldehyde, 4-(1-methylethyl) 0.170; Cyclohexene, 3-methyl-6-(1-methylethyl) 0.108; 2- cyclohexene-1-ol, 2-methyl-5-(1methylethenyl)-, trans- 0.059; 2, 3-dimethyl-cyclohexa-1, 3-diene 0.390; $\alpha$-campholonic acid 0.049; Furan, 2, 3-dihydro-4-(1-methylpropyl) 0.458; (E)-3-isopropyl-6-oxo-2-heptenal 0.058; 1, 5, 5-trimethyl-6-methylenecyclohexene $0.056 ; 2,6$, 10-trimethyl-2, 5:7, 10-dioxido- dodeca-3, 11-diene-5-ol 0.268; Tricyclo [6.3.0.1(2, 3)] undec-7-ene, 6, 10, 11, 11-tetramethyl 0.138; 1-methyl-4-isopropyl-cis-3- hydroxycyclohex-1-ene-6-one 0.230; 1H-cyclopropa[a]naphthalene, $\quad$ decahydro- $\quad 1,1,3 \quad$ a-trimethyl-7-methylene-, [1as(1a.1alpha.,3a.alpha.,7a.beta.,7b.alpha.)] 0.235; Naphthalene, 1, 2, 3, 4, 4a, 7- hexahydro-1, 6- dimethyl-4(1-methylethyl) 0.139; Bicyclo[3.1.0]hex-2-ene,2-methyl-5- (1-methylethyl) 0.026; +)-(1R, 2S, 4R, 7R)-7isopropyl-5- methyl-5- bicycle [2.2.2] octen-2-ol 0.140 and 1, 6-dimethyl-2-cyano-3-ethyl-3-piperidine 0.612 [109]. 


\section{Pharmacological effects:}

Eucalyptus, with almost 900 species, is found worldwide, More than 300 species of this genus contain volatile oils in their leaves [110]. There were three broad categories of uses for Eucalyptus oil (medicinal, industrial and perfumery/flavouring). Medicinal oils were defined by the British Pharmacopoeia as containing not less than $70 \%$ cineole; industrial oils contain principally piperitone and phellandrene as main constituents, and perfumery and flavouring oils contain high percentages of citronella1 (a lemon scent) and geranyl acetate (a rose scent). Medicinal oils were used primarily as a decongestant agent and antiseptic in inhalants, sprays, embrocations, gargles and lozenges. It was also prepared as emulsions, ointments and other preparations. Industrial oils were used in the manufacture of disinfectants, deodorants, liquid soaps, germicides and in the manufacture of synthetic menthol and thymol. Perfumery and flavouring oils were used either directly as a scenting agent and food flavouring, or in the synthesis of other scents and flavor [84].Medicinal Eucalyptus oil was produced from Eucalyptus globulus in China, Portugal, Spain, India, Brazil Bolivia, Uruguay and Paraguay; and from Eucalyptus smithii in South Africa, Swaziland, and Zimbabwe; from Eucalyptus polybractea, Eucalyptus viridis and Eucalyptus dives in Australia; from Eucalyptus radiata in South Africa and Australia; and from Eucalyptus camaldulensis in Nepal. Perfumery Eucalyptus oil was produced from Eucalyptus citriodora in China, Brazil and India; and from Eucalyptus staigeriana in Brazil. Industrial Eucalyptus oil was produced from Eucalyptus dives in south Africa and Australia; and from Eucalyptus campanulata in Australia [111].

\section{Gastrointestinal effects:}

The ulcer-healing promoting effect of the methanol extracts of Eucalyptus camaldulensis leaves was investigated in acetic acid induced-ulcer in rat. The results showed that methanol extracts of Eucalyptus camaldulensis leaves reduced the size of the ulcer from day 5 in animals treated with $500 \mathrm{mg} / \mathrm{kg}$ body weight of reconstituted extracts at 24 hours interval. At the end of the experiment (day 14) most of the ulcers has reduced by half the original size with $46.67 \pm 3.33 \%$ decrease in diameter compared to the controls (distilled water and ranitidine) which afforded $21.67 \pm 1.05 \%$ and $59.17 \pm 1.54 \%$ decrease in diameter respectively [112]. The in vitro anti- Helicobacter pylori of Eucalyptus camaldulensis was investigated in six strains of Helicobacter pylori (ATCC 4504, ATCC 47619, A2, TI8984, 019A, and A6). The minimum inhibitory concentrations of the crude extracts against all the tested strains ranged from 12.5 to $400 \mathrm{~m} \mu \mathrm{g} / \mathrm{ml}$ [113]. A new triterpenoid acid, eucalyptanoic acid isolated from the fresh uncrushed leaves of Eucalyptus camaldulensis var obtusa along. This compound and its acetyl and acetylmethyl derivatives were tested for spasmolytic activity. The acetylmethyl derivative was found to be the most active spasmolytic agent, its effect was mediated through

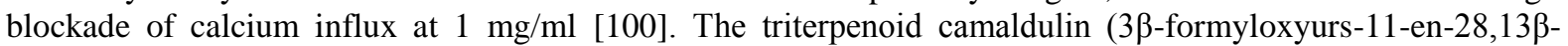
olide), ursolic acid lactone acetate and ursolic acid lactone isolated from Eucalyptus camaldulensis var. obtuse, showed spasmolytic activity and possessed calcium antagonist activity [101].

\section{Antiinflammatory and analgesic effect:}

1,8-Cineole (cineole) possessed an inhibitory effect on some types of experimental inflammation in rats, (paw oedema induced by carrageenan and cotton pellet-induced granuloma). Cineole also inhibited the acetic acid-induced increase in peritoneal capillary permeability and the chemical nociception induced by intraplantar formalin and intraperitoneal acetic acid in mice at an oral dose range of $100-400 \mathrm{mg} / \mathrm{kg}$. In the formalin test, the antinociceptive effect of cineole was not reversed by pretreatment of mice with naloxone (1 $\mathrm{mg} / \mathrm{kg}, \mathrm{sc}$ ), a mu-opioid receptor antagonist, suggesting the involvement of a non-opioid mechanism. Cineole demonstrated a significant inhibitory effect on locomotion and also potentiated the pentobarbital sleeping time in mice, indicating a depressant effect on the central nervous system [114].The effect of 1.8-cineole was evaluated on arachidonic acid (AA) metabolism in blood monocytes of patients with bronchial asthma. Production of the representative AA-metabolites LTB4 and PGE2 from isolated monocytes stimulated with the calcium ionophore A23187 were measured ex vivo before therapy with 1.8-cineole ( 3 x $200 \mathrm{mg} /$ day), after three days of treatment (day 4) and four days after discontinuation of 1,8-cineole (day 8). The production of LTB4 and PGE2 from monocytes ex vivo was significantly inhibited on day 4 in patients with bronchial asthma ($40.3 \%, \mathrm{n}=10$ and $-31.3 \%, \mathrm{p}=0.1, \mathrm{n}=3$ respectively) as well as in healthy volunteers $(-57.9 \%, \mathrm{n}=12$ and $42.7 \%, \mathrm{n}=8$ respectively). In conclusion, 1,8-cineole was shown to inhibit LTB4 and PGE2, both pathways of AA-metabolism [115]. In studying the potential anti-inflammatory efficacy of 1,8-cineol (eucalyptol) in inhibiting polyclonal stimulated cytokine production by human unselected lymphocytes and LPS-stimulated monocytes, the therapeutic concentrations of 1,8 -cineol $(1.5 \mu \mathrm{g} / \mathrm{ml}=10-5 \mathrm{M})$ inhibited significantly $(\mathrm{p}=0.0001)$ cytokine production in lymphocytes of TNF- $\alpha$, IL-1 $\beta$, IL-4, IL- 5 by $92,84,70$, and $65 \%$, respectively. Cytokine production in monocytes of TNF- $\alpha$, IL-1 $\beta$, IL-6, IL-8 was also significantly $(\mathrm{P}<0.001)$ inhibited by $99,84,76$, and $65 \%$, respectively. In the presence of $1,8-\operatorname{cineol}(0.15 \mu \mathrm{g} / \mathrm{ml}=10-6 \mathrm{M})$, the production of TNF- $\alpha$ and IL- $1 \beta$ by monocytes and lymphocytes was significantly inhibited by 77,61 and $16,36 \%$, respectively [116]. The 
effect of Eucalyptus essential oils (EO) was studied on the phagocytic ability of human monocyte derived macrophages (MDMs) in vitro and of rat peripheral blood monocytes/granulocytes in vivo in absence or in presence of immuno-suppression induced by the chemotherapeutic agent 5-fluorouracil (5-FU). Eessential oil was able to induce activation of MDMs and dramatically stimulating their phagocytic response. Implementation of innate cell-mediated immune response was also observed in vivo after essential oil administration, mainly involving the peripheral blood monocytes/granulocytes. The 5-FU/EO combined treatment inhibited the 5-FU induced myelotoxicity and raised the phagocytic activity of the granulocytic/ monocytic system, significantly decreased by the chemotherapic [117].The inhibitory effect of 1,8-cineole was studied on LPS-and IL1beta-stimulated mediator production by human monocytes in vitro. A dose-dependent and highly significant inhibition of production of tumor necrosis factor-alpha, interleukin-1beta, leukotriene B4 and thromboxane B2 were achieved by 1,8-cineole [118]. 1,8-cineole and beta-pinene, two monoterpenes isolated from the essential oil of Eucalyptus camaldulensis leaves were tested for antinociceptive properties. Tail-flick and hot-plate methods, reflecting the spinal and supraspinal levels, respectively, were used in mice and/or rats using morphine and naloxone for comparison. Cineole exhibited an antinociceptive activity comparable to that of morphine, in both algesic stimuli. A significant synergism between cineole and morphine was observed, but naloxone failed to antagonize the effect of cineole. Beta-pinene exerted supraspinal antinociceptive actions in rats only, and it reversed the antinociceptive effect of morphine in a degree equivalent to naloxone, probably acting as a partial agonist through the mu opioid receptors [119].

Eucalyptus camaldulentis possessed an anti-nociceptive effect against both acetic acid-induced writhing and hot plate-induced thermal stimulation in mice [120].

\section{Antioxidant effect:}

The effects of 1,8-cineole on systolic blood pressure (SBP) and oxidative stress was investigated in rats chronically exposed to nicotine. $0.1 \mathrm{mg} / \mathrm{kg} 1,8$-cineole significantly reduced $\mathrm{SBP}$, and $1 \mathrm{mg} / \mathrm{kg} 1,8$ cineole significantly increased plasma nitrite concentrations, compared with rats chronically exposed to nicotine alone. Rats chronically exposed to nicotine showed a significant increase in lipid peroxidation levels, an elevation significantly antagonized by treatment with 0.01 and $0.1 \mathrm{mg} / \mathrm{kg} 1,8$-cineole. Chronic exposure to nicotine also significantly increased plasma corticosterone levels, but this effect was not diminished by treatment with 1,8-cineole [121].The in vitro antioxidant activities of the essential oil and the subfractions of methanol extract from leaves of Eucalyptus largiflorens (Eucalyptus bicolor) were investigated using 2,2diphenyl-1-picrylhydrazyl (DPPH) and $\beta$-carotene-linoleic acid assays. In DPPH, the $\mathrm{IC}_{50}$ of polar subfractions of the methanol extract was lower than that of non polar one, while in the case of the linoleic acid system; oxidation of the linoleic acid was effectively inhibited by the non polar subfraction of the methanol extract (92 $94.5 \%$ ), which was comparable to the synthetic antioxidant BHT. In both evaluating methods, the oils were less effective. The amounts of total phenolics in the polar subfractions of each extracts were positively correlated with the antioxidant activity [122].The antioxidant activity of the essential oil and methanol extracts of Eucalyptus largiflorens (Eucalyptus bicolor) was studied in vitro. The extract showed better antioxidant activity than the essential oil. Also, the polar subfraction of methanol extract showed the highest radicalscavenging activity. The inhibition capacity $(\%)$ of the nonpolar subfraction was found to be the stronger one [123]. The free radical scavenging activities of the Eucalyptus camaldulensis essential oil were assessed by measuring their scavenging abilities for stable 2,21-diphenyl-1-picrylhydazyl DPPH radicals. The DPPH scavenging activity was high in Eucalyptus camaldulensis (81.9\%) [124]. The results of evaluation of antioxidant effect of essential oil of Eucalyptus camaldulensis indicated that the essential oil had weak radical scavenging activity comparing with ascorbic acid and Butylated hydroxyanisole, while it had high potent ferrous ions chelating and total antioxidant activities comparing to ascorbic acid and BHT [125]. The leaves extract of Eucalvptus camaldulensis var. brevirostris, grown in Nile delta in Egypt, were examined for the antioxidant activity. The extracts obtained by ethanol digestion and by supercritical fluid extraction showed the most promising antioxidative activities. In order to identify the most active compounds, the contents of both extracts were separated by reversed-phase HPLC. Gallic and ellagic acid were found to be the prevailing antioxidants in the ethanolic extract [126]. The antioxidant activity of the essential oils of Eucalyptus camaldulensis, was assessed by DPPH-test and expressed as Trolox equivalent antioxidant capacity, they showed values ranging between 0.5 and $5.8 \mathrm{mmol} / \mathrm{l}$ [98].The antioxidant activities of Eucalyptus camaldulensis, Eucalyptus camaldulensis var. obtusa and Eucalyptus gomphocephala essential oils was studied (2,2'-diphenypicrylhydrazyl). The values of total antioxidant activity were $70 \pm 3.13 \%, 50 \pm 3.34 \%$ and $84 \pm$ $4.64 \%$ for of Eucalyptus camaldulensis, Eucalyptus camaldulensis var. obtusa and Eucalyptus gomphocephala, respectively. The highest antioxidant activity value of $84 \pm 4.64 \%$ could be attributed to the high amount of spathulenol (37.46\%) [127].The effects of essential oil from Eucalyptus camaldulensis flowers oil on melanogenesis and the oil's antioxidant characteristics were investigated. Assays of mushroom and cellular tyrosinase activities and melanin content of mouse melanoma cells were performed spectrophotometrically, and 
the expression of melanogenesis-related proteins was determined by Western blotting. The possible signaling pathways involved in essential oil-mediated depigmentation were also investigated using specific protein kinase inhibitors. Eucalyptus camaldulensis flower essential oil inhibited melanogenesis through its antioxidant properties and by down-regulating both mitogen-activated protein kinases (MAPK) and protein kinase A (PKA) signaling pathways. The study indicated that the essential oil has the potential to be developed into a skin care product [97].The free radical scavenging activities of the Eucalyptus microtheca essential oil were assessed by measuring their scavenging abilities for stable 2,21-diphenyl-1-picrylhydazyl DPPH radicals. The DPPH scavenging activity was high in Eucalyptus microtheca $(81.8 \%)$ [124].

\section{Cytotoxic effect:}

The anti-proliferative effect of 1,8-cineole was studied on human colon cancer cell lines HCT116 and RKO by WST- 8 and BrdU assays. The cytotoxicity of 1,8-cineole was investigated by LDH activity and TUNEL staining. The mechanism of apoptosis by 1, 8-cineole was determined by western blot analyses. In in vivo study, RKO cells were injected into the mice and the effect of 1,8-cineole was investigated. Specific induction of apoptosis, not necrosis, was observed in human colon cancer cell lines HCT116 and RKO by 1, 8cineole. The treatment with 1,8-cineole was associated with inactivation of survivin and Akt and activation of p38. These molecules induced cleaved PARP and caspase-3, finally causing apoptosis. In xenotransplanted mice, 1, 8-cineole significantly inhibited tumor progression compared to the control group [128].14 plant species used in traditional medicine in Yemen were screened for cytotoxic activity against human ECV -304 cells. Extracts of Eucalyptus camaldulensis possessed a remarkable cytotoxic activity [129].Eucalyptus camaldulensis leaves essential oil demonstrated cytotoxic effects in three tested cancer cell lines; WEHI-3, HT29 and HL-60. WEHI-3 was the most sensitive with $\mathrm{IC}_{50}=16.10 \mu \mathrm{g} / \mathrm{ml}$. The essential oil exhibited less cytotoxic effects in HT-29 and HL-60 cells ( $\mathrm{IC}_{50}=50.5$ and $42.10 \mu \mathrm{g} / \mathrm{ml}$, respectively). Essential oil also exhibited a weak cytotoxic effect in RAW 264.7 cells [130]. The cytotoxicity of the aqueous acetone extract was evaluated on MCF-7, Hep-2, HepG-2, HeLa, HCT-116 and Caco-2 cell lines. The extract reduced the viability of all cell lines in a dose-dependent manner, and was more active on MCF-7 and HCT-116 cell lines. IC ${ }_{50}$ ranged from 33.3 to $57.7 \mu \mathrm{g} / \mathrm{ml}$ [103]. The cytotoxic effects of essential oil of Eucalyptus camaldulensis was evaluated in different cancer and normal cell lines, the essential oil showed high potent cytotoxic effect on colon, prostate and breast cancer cell lines as well as moderate potency against liver and lung cell lines with $\mathrm{IC}_{50} 19.8,31.5$, $34.9,51.7$ and $64.0 \mu \mathrm{g} / \mathrm{ml}$ respectively. In the same pattern, the oil showed high cytotoxic effect on normal epithelial retina cell line and moderate effect on normal skin fibroblast cell with $\mathrm{IC}_{50} 41.3$ and $60.6 \mu \mathrm{g} / \mathrm{ml}$ respectively [125].

In vitro cytotoxicity of methanol, ethyl acetate, $n$-buthanol, and water extracts of Eucalyptus camaldulensis leaves was examined against two human breast cancer cell lines (MCF 7 and MDA-MB-231) using MTT and SRB assays. The results showed that the extracts possessed significant cytotoxic potential with $\mathrm{IC}_{50}$ values ranging from 3 to $250 \mu \mathrm{g} / \mathrm{ml}$ [131]. Anticancer activities of $p$-menth-1-ene-4,7-diol (EC-1) isolated from Eucalyptus camaldulensis were studied on Ehrlich ascites carcinoma (EAC) cells. Anticancer activities also analyzed in EAC-bearing mice by assessment of cancer growth inhibition, changes in cancer volume, changes in life span, and hematological parameters. Apoptosis was analyzed by fluorescence microscope, DNA fragmentation assay, and flow cytometry. The expression of apoptosis-related genes, $B c l-2, B c l-X, P A R P$ $1, p 53$, and Bax, were analyzed using polymerase chain reaction (PCR). p-menth-1-ene-4,7-diol (EC-1) significantly inhibited proliferation of EAC cells in vivo and restored the altered hematological parameters of EAC-bearing mice. Cytological observation by fluorescence microscope showed apoptosis of EAC cells upon treatment with EC-1. Also, DNA fragmentation assay revealed EAC cells' apoptosis following EC-1 treatment. Increased mRNA expressions of $p 53$ and $B a x$ genes and negative expressions of $B c l-2$ and $B c l-X$ were observed in cells treated with EC-1. MTT assay showed dose-dependent anticancer activity of EC-1 against EAC cell. Cell cycle analysis revealed that EC-1 treatment caused suppression of EAC cells at S phase [132]. The cytotoxic effect of the crude methanolic extracts of Eucalyptus camaldulensis was investigated against L20B (a genetically engineered mouse cell line) and human rhabdomyo sarcoma (RD) cells showed that the extract of Eucalyptus camaldulensis possessed moderate cytotoxicity [133]. The in vivo antitumor effect of Eucalyptus camaldulensis stem bark methanol extract was studied against Ehrlich's ascites carcinoma (EAC) in Swiss albino mice. Eucalyptus camaldulensis stem bark methanol extract showed $96 \%(\mathrm{P}<0.001)$ cell growth inhibition and reduced tumor burden significantly $(81.4 \% ; \mathrm{P}<0.01)$ when compared with control mice. It also increased the lifespan of EAC-bearing mice significantly $(71.36 \% ; \mathrm{P}<0.01)$. In addition, it also restored the altered hematological and biochemical parameters towards normal level. The high $\mathrm{LD}_{50}$ value $(1120 \mathrm{mg} / \mathrm{kg})$ of Eucalyptus camaldulensis stem bark methanol extract indicated its low host toxic effects. Eucalyptus camaldulensis stem bark methanol extract -treated EAC cells showed membrane blebbing, chromatin condensation, nuclear fragmentation (apoptotic features) in Hoechst 33342 staining under 
fluorescence microscope. The DNA profile in agarose gel $(1.5 \%)$ electrophoresis also confirmed that Eucalyptus camaldulensis stem bark methanol extract caused EAC cell death by apoptosis [134].

\section{Antiparasitic, insecticidal and repellent effects}

In studying anti- schistosomal effect of Eucalyptus essential oil, the scanning electron microscope observation showed that of essential oil produced sever damage in schistosoma worm's typography [135]. The effect of the leaves, stem and root barks extracts of Eucalyptus camaldulensis was investigated in Trypanosoma brucei infected mice. $200-600 \mathrm{mg} / \mathrm{kg}$ body weight/day of the hexane, ethyl acetate, methanol and water extracts for 21 consecutive days. One control group was treated with $3.5 \mathrm{mg} / \mathrm{kg}$ bodyweight of berenil while the other control group was left untreated. The methanol extract of Eucalyptus camaldulensis (leaf) produced complete cure for the animals in the different dose groups and survived as long as those treated with the standard drug, berenil, although the clearance time was faster for the standard drug. Sub inoculation of healthy mice with the blood and cerebrospinal Fluid (CSF) of the cured mice did not result in infection, thus indicating a complete and permanent cure. Bioassay-guided fractionation of the crude methanol extract of Eucalyptus camaldulensis leaf gave 10 fractions, only fractions 8 and 9 exhibiting minimal antitrypanosomal activities that were not comparable to those of the crude extract and the standard drug $(\mathrm{p} \leq 0.05)$ [136]. The effect of methanolic and aqueous extracts of Eucalyptus camaldulensis was studied on the promastigotes of Leishmania major. The stationary phase promastigotes of Leishmania major was incubated in the methanolic and aqueous extractions in vitro. Tartar emetic was used as the positive control drug. After $72 \mathrm{~h}$ of incubation, the activity of the extracts was measured, using MTT method. The $\mathrm{IC}_{50}$ values were $586.2 \pm 47.6$ and $1,108.6 \pm 51.9 \mu \mathrm{g} / \mathrm{ml}$ for methanolic and aqueous extracts, respectively, whereas it was $32.5 \pm 6.8 \mu \mathrm{g} / \mathrm{ml} \mathrm{for}$ tartar emetic [137]. The effect of different extracts of Eucalyptus camaldulensis (total extract, diethyl ether, chloroform, ethyl acetate, and water fractions) on $T$. vaginalis was investigated in culture medium. Crude extract of Eucalyptus camaldulensis showed $80 \%$ growth inhibition in a concentration of $12.5 \mathrm{mg} / \mathrm{ml}$ during $24 \mathrm{~h}$. Diethyl ether extract in a concentration of $25 \mathrm{mg} / \mathrm{ml}$ showed $100 \%$ growth inhibition during $24 \mathrm{~h}$. With ethyl acetate extract, $100 \%$ growth inhibition was detected with the minimum concentration of $12.5 \mathrm{mg} / \mathrm{ml}$ in the first $24 \mathrm{~h}$. Water extract in a concentration of $50 \mathrm{mg} / \mathrm{ml}$ showed $80 \%$ and $100 \%$ growth inhibition after 48 and $72 \mathrm{~h}$, respectively [138].Eucalyptus essential oil showed a wide biological activity against insects, nematodes, weeds and mites. The use of Eucalyptus oil as a natural pesticide was of immense significance in view of the environmental and toxicological implications of the indiscriminate use of synthetic pesticides and vercoming/reducing the problem of increasing pest resistance [139].The larvicidal activity of Eucalyptus camaldulensis was studied against Anopheles stephensi. The leaf extract and volatile oil exerted significant larvicidal activity with $\mathrm{LC}_{50}$ values of 89.85 and $397.75 \mathrm{ppm}$, respectively. Clear dose-response relationships were established, with the highest dose of $320 \mathrm{ppm}$ essential oil extract resulted almost in $100 \%$ mortality in the population [140]. Vapors of essential oils extracted from Eucalyptus camaldulensis and its major components were found to be toxic to Aedes aegypti adults, the yellow fever mosquito. An aliquot of oil was placed in a cylindrical test chamber and the number of knocked-down mosquitoes was recorded as function of time. Knockdown time $50 \%$ was then calculated. A correlation was observed between the content of 1,8-cineole in the Eucalyptus essential oils and the corresponding toxic effect. The correlation between $\mathrm{KT}_{50}$ values and calculated vapor pressures of the essential oil components showed that the fumigant activity of simple organic compounds in insects was correlated with their volatility [141].The mosquito larvicidal activity of leaf essential oils of Eucalyptus camaldulensis and their constituents was investigated against two mosquito species, Aedes aegypti and Aedes albopictus, Essential oil of the leaves of Eucalyptus camaldulensis had an excellent inhibitory effect against both Aedes aegypti and Aedes albopictus larvae. The 12 pure constituents extracted from the Eucalyptus leaf essential oils were also tested individually against two mosquito larvae. Among the six effective constituents, alpha-terpinene exhibited the strongest larvicidal effect against both Aedes aegypti and Aedes albopictus larvae [142]. Eucalyptus essential oil can act directly as a natural insect repellent. Eucalyptus essential oil can protect plants against rice weevils, pine processionary moths and mushroom flies [139].Essential oils extracted from the dried fruits of Eucalyptus camaldulensis, and essential oils of many other plants were tested for their repellency against the adult females of Culex pipiens. The essential oils showed repellency in varying degrees, Eucalyptus, basil and anise being the most active [143].The insecticidal effects of hot and cold aqueous Eucalyptus microtheca leaves extracts were studied on mosquito Culex pipiens. Hot water extract was more effective on immature stages of insect. Eggs mortality rate of the hot and cold extracts was $51 \%$ and $47.3 \%$ respectively at a concentration of $20 \mathrm{mg} / \mathrm{ml}$. Larval mortalities rate was significantly increased in hot and cold water extracts as compared with control. The hot and cold extracts caused $31.5 \%$ and $28.6 \%$ pupal mortality at concentration of $20 \mathrm{mg} / \mathrm{ml}$, respectively [144]. The accumulative and non accumulative effects of aqueous and organic extracts of the leaves of Eucalyptus microtheca was investigated on larvae of Culex quinqefasciatus. The petroleum ether extract was the most effective, however, all extracts increased the duration of larval stage and caused morphological changes of larva [53]. 


\section{Antimicrobial effect:}

The antibacterial effect of Eucalyptus oil was investigated against Klebsiella spp., Proteus spp., Pseudomonas spp., Escherichia coli, and Staphylococcus aureus. The results showed that, Escherichia coli and Klebsiella spp. were sensitive to $5 \mu \mathrm{l}$, Staphylococcus aureus to $25 \mu \mathrm{l}$, while Pseudomonas and Proteus spp. required $50 \mu \mathrm{l}$ of Eucalyptus oil. With an increasing dose of oil of Eucalyptus, the resulting diameter of the zone of inhibition increased for all the organisms [145]. The in vitro antimicrobial activity of the essential oil and methanol extracts of Eucalyptus largiflorens (Eucalyptus bicolor) was studied against Aspergillus niger ATCC 16404, Candida albicans ATCC 10231, Pseudomonas aeruginosa ATCC 27853, Bacillus subtilis ATCC 6633, Staphylococcus aureus ATCC 29737, Escherichia coli ATCC 10536, Klebsiella pneumoniae ATCC 10031, Staphylococcus epidermidis ATCC 12228, Shigella dysenteriae PTCC 1188, Proteus vulgaris PTCC 1182 and Salmonella paratyphi-A serotype ATCC 5702. The essential oil of Eucalyptus largiflorens exhibited moderate to high antimicrobial activity against all the bacteria, yeast and mold tested, except three microorganisms, Pseudomonas aeruginosa, Escherichia coli and Shigella dysenteriae. The evaluation of methanol fraction indicated that polar fraction showed strong activity against 7 out of 11 microorganisms while non-polar fractions did not posses any inhibitory action against the strains evaluated except Escherichia coli [123].The antimicrobial properties of essential oil, its major component, 1,8-cineole, and extracts of Eucalyptus largiflorens (Eucalyptus bicolor) were evaluated in vitro. Minimum inhibitory concentration of the extracts was calculated by broth dilution method and the zone of inhibition was studied by agar disk diffusion method. Gentamicin (10 $\mu \mathrm{g} / \mathrm{disk})$ and rifampin $(5 \mu \mathrm{g} / \mathrm{disk})$ were used as reference controls for antibacterial, and nystatin $(100 \mu \mathrm{g} / \mathrm{disk})$ for antifungal tests. The results of MIC study revealed that the essential oil has a stronger activity and broader spectrum than those of methanol extracts. The oil also had greater antimicrobial potential than 1,8-cineole [146].Disk diffusion method was used to determine the antimicrobial activity of aqueous extract and essential oils of Eucalyptus incrassata leaves against eight isolates of multidrug- resistant Staphylococcus aureus. It was found that aqueous extract and essential oils possessed variable antimicrobial activity (the inhibition zone diameter ranged from 7 to $14 \mathrm{~mm}$ respectively). Essential oils showed more antibacterial effect than aqueous extract [104]. The in vitro antimicrobial activity of acetone, methanol and water extracts of leaf, stem and bark of Eucalyptus camaldulensis was studied against six bacterial species Bacillus megaterium, Bacillus subtilis, Staphylococcus epidermidis Staphylococcus aureus, Micrococcus luteus and E. coli using the agar well diffusion method. The results showed that the extracts exhibited a dose-dependent inhibition of microorganisms. The acetone and methanol extracts of leaf and stem bark of Eucalyptus camaldulensis displayed maximum antibacterial activity against all the bacterial species. There was no significant difference in the antimicrobial activity of the extracts on Gram negative and Gram positive bacteria [147]. The antibacterial activity of the crude leaf extracts of Eucalyptus camaldulensis were studied against clinical isolates of Escherichia coli, Staphylococcus aureus, Salmonella typhi, Proteus mirabilis and Klebsiella pneumoniae. The growth of all the pathogenic bacteria was arrested at $50 \mathrm{mg} / \mathrm{ml}$ concentration of extracts. The least activity was possessed by aqueous extract against E. coli $(7 \mathrm{~mm})$, K. pneumoniae $(9 \mathrm{~mm})$, P. mirabilis $(13 \mathrm{~mm})$, S. typhi $(12$ $\mathrm{mm}$ ) and $S$. aureus $(12 \mathrm{~mm})$, while the highest was recorded for the acetone extract, with a diameter of inhibition for E. coli $(12 \mathrm{~mm})$, K. pneumonia $(13 \mathrm{~mm})$, S. typhyi $(14 \mathrm{~mm})$, P. mirabilis $(15 \mathrm{~mm})$ and S. aureus (14 mm) [148]. The antibacterial activities of Eucalyptus camaldulensis, Eucalyptus camaldulensis var. obtusa and Eucalyptus gomphocephala essential oils were studied using agar disc diffusion and minimum inhibitory concentration methods. The essential oils from the leaves of Eucalyptus spp. exhibited considerable antibacterial activity against Gram positive and Gram negative bacteria [127].The antimicrobial and biofilm preventing activities of the oils of Eucalyptus camaldulensis were studied in vitro and in vivo. Minimal bactericidal concentrations (MBC) of the Eucalyptus camaldulensis oils were found to be 4 and $2 \mathrm{mg} / \mathrm{ml}$, and those of chlorhexidine (2\%) were 8 and $1 \mathrm{mg} / \mathrm{ml}$ for both $S$. mutans and S. pyogenes respectively. Decimal reduction time of S. mutans by Eucalyptus camaldulensis oils at their MBC levels was 2.8 min, while that of cholrhexidine was $12.8 \mathrm{~min}$. D-value of S. pyogenes exposed to the MBC levels of Eucalyptus camaldulensis oils and of chlorhexidine were 3.6 and 2.8 min respectively. Antibacterial and in vivo biofilm preventive efficacies of all the concentrations of Eucalyptus oil were significantly $(\mathrm{P}<0.001)$ higher than that of chlorhexidine [149].

The antimicrobial potential of two Eucalyptus camaldulensis essential oils was investigated against multi-drug resistant (MDR) Acinetobacter baumannii wound isolates, the possible interactions of essential oils with conventional antimicrobial agents was also studied. MIC values of essential oils against Acinetobacter baumannii strains were estimated by modified broth microdilution method. The components responsible for antimicrobial activity were detected by bioautographic analysis. The potential synergy between the essential oils and antibiotics (ciprofloxacin, gentamicin and polymyxin B) was examined by checkerboard method and time kill curve. The bioautographic assay confirmed antibacterial activity of polar terpene compounds. In combination with conventional antibiotics (ciprofloxacin, gentamicin and polymyxin B), the examined essential 
oils showed synergistic antibacterial effect. The synergistic interaction was confirmed by time-kill curves for Eucalyptus camaldulensis essential oil and polymyxin B combination which reduced bacterial count under detection limit very fast, after $6 \mathrm{~h}$ of incubation [150]. The in vitro antimicrobial activities of the crude oil of Eucalyptus camaldulensis leave was investigated against Escherichia coli and Staphylococcus aureus. The diameter of zones of inhibition by the crude oil of leaf extracts of Eucalyptus camaldulensis was 10- 31mm and 10-26mm for Escherichia coli and Staphylococcus aureus. Gram positive, Staphylococcus aureus was more resistant than Gram negative, Escherichia coli [151]. The in vitro anti- Helicobacter pylori of Eucalyptus camaldulensis was investigated in six strains of H. pylori (ATCC 4504, ATCC 47619, A2, TI8984, 019A, and A6). The minimum inhibitory concentrations of the crude extracts against all the tested strains ranged from 12.5 to $400 \mathrm{mug} / \mathrm{ml}$ [113]. Hexane, chloroform, methanol extracts, and isolated compounds of Eucalyptus camaldulensis were screened for activity against Mycobacterium tuberculosis $\mathrm{H} 37 \mathrm{Rv}$ (MtbH37Rv). The extracts inhibited the growth of Mycobacterium tuberculosis with MIC of 4-64 $\mu \mathrm{g} / \mathrm{ml}$. Spectroscopic characterization led to the identification of two compounds, hydroxymyristic acid methylester and a substituted pyrenyl ester, a sterol. These two compounds had MIC of 49.45 and $46.99 \mu \mathrm{g} / \mathrm{ml} ; \mathrm{IC}_{50}>100$ and $38.21 \mu \mathrm{g} / \mathrm{ml}$; selectivity index (SI) $>2.02$ and 0.81 , respectively, and a minimum bactericidal concentration of $62.50 \mu \mathrm{g} / \mathrm{ml}$ [152].Essential oil of the leaves of Eucalyptus camaldulensis possessed high antibacterial effects against Gram positive and negative bacteria with inhibition zones ranged from 9.3 to $12.5 \mathrm{Mm}$. The same effect was observed against yeast (21\% inhibition) and fungi (10\% inhibition) [135]. The antibacterial effect of essential oil of Eucalyptus camaldulensis was evaluated against L. monocytogenes, S. aureus, E. coli, K. pneumoniae, S. cerevisiae, C. albicans, M. ramamnianus and A. ochraceus. Essential oil of Eucalyptus camaldulensis showed activity against $S$. aureus $(21 \mathrm{~mm})$, B. subtilis $(24 \mathrm{~mm})$ and E. coli $(10 \mathrm{~mm})$. Significant anti fungal activity was also shown by essential oil of Eucalyptus camaldulensis against A. niger (28mm) and $R$. solani $(12 \mathrm{~mm})$ [124]. Methanolic leaf extracts of Eucalyptus camaldulensis were investigated for in vitro antifungal activities against Microsporum canis, Microsporum gypseum, Tricophyton rubrum, Tricophyton schoenleinii, Tricophyton mentagrophytes and Epedermophyton floccosum. Eucalyptus camaldulensis showed antifungal activity against all the tested dermatophytes with MIC values ranging from 0.4 to $1.6 \mathrm{mg} / \mathrm{ml}$ [153]. The essential oils of Eucalyptus camaldulensis were screened for their antifungal activities against common phytopathogenic fungi using the paper disk diffusion method, they showed activity at low doses against the tested fungi [98]. The antiviral effect of the leaf essential oil of Eucalyptus camaldulensis was studied against many viruses. Rotavirus Wa strain, Coxsackievirus B4, and herpes virus type 1 were affected by essential oil with percentage of reduction $50 \%, 53.3 \%$, and $90 \%$ respectively, but no effect was found against adenovirus type 7 [135]. The methanolic extracts of Eucalyptus camaldulensis was tested against human enteroviruses: Poliovirus type I, Coxsackievirus B and Echovirus 6. The virucidal tests showed that the crude extracts were active against the tested viruses. Poliovirus type 1, coxsackievirus B and echovirus 6 giving a neutralization index of one $\log$ and above [133]. The aqueous, ethanolic, chloroform and acetone extracts of Eucalyptus microtheca showed inhibitory effects against Staphylococcus aureus while benzene extract was not effective. The aqueous, ethanolic and acetone extracts also possessed inhibitory effects against S. typhimurium. The extracts also showed synergistic inhibitory activity when combined with antibiotics against both Staph. aureus but not against S. typhimurium [54].The antibacterial activity of Eucalyptus microtheca leaves crude (ethanolic, methanolic and aqueous) extracts were tested against Pseudomonas aeruginosa isolates. All crude extracts exhibited an in vitro antibacterial activity against all Pseudomonas aeruginosa isolates with a zone of inhibition ranged between $17-25 \mathrm{~mm}$ for methanolic extract, $20-29 \mathrm{~mm}$ for ethanolic extract at a concentration of $1 \mathrm{mg} / \mathrm{ml}$, while the zone of inhibition for aqueous extract was 12-16mm [154].The antibacterial activity, MIC, and MBC of alcoholic extracts of Eucalyptus microtheca were studied against Bacillus cereus, Staphylococcus aureus, Salmonella typhi, Escherichia coli, Pseudomonas aeruginosa, Klebsiella pneumonia, and Proteus mirabilis using standard disk diffusion method. The structural changes following the exposure to these extracts were also investigated in the tested bacteria. Significant antibacterial activity was found against Gram positive and Gram negative bacteria, among them, Escherichia. Coli and Pseudomonas. aeruginosa showed the most sensitivity and Staphylococcus aureus the least. The value of MIC and MBC for both extracts were $8 \mathrm{mg} / \mathrm{ml}$ for E. coli, 8 and $16 \mathrm{mg} / \mathrm{ml}$ for Bacillus cereus, respectively. MIC and MBC values of methanolic and ethanolic extracts against $P$. aeruginosa were 8 and $16 \mathrm{mg} / \mathrm{ml}$ respectively. Scanning electron microscopy revealed structural changes in the affected bacteria, which suggested that the cell wall was the main target site of active constituents [155]. The antibacterial effect of essential oil of Eucalyptus microtheca was evaluated against L. monocytogenes, S. aureus, E. coli, K. pneumoniae, S. cerevisiae, C. albicans, M. ramamnianus and A. ochraceus. Essential oil of Eucalyptus microtheca showed activity against $S$. aureus (16mm), B. subtilis $(20 \mathrm{~mm})$ and E. coli $(11 \mathrm{~mm})$. Significant antifungal activity was shown by essential oil of Eucalyptus microtheca against $A$. niger $(21 \mathrm{~mm})$ and $R$. solani $(17 \mathrm{~mm})$ [124]. The antifungal activity of the Eucalyptus microtheca leaves crude aqueous, ethanolic and methanolic extracts were tested in vitro by agar well diffusion method against Penicillium digitatum and Aspergillus niger. Alcoholic extracts significantly inhibited the 
mycelial growth of $P$. digitatum and A. niger more than aqueous extracts. Methanolic extracts showed higher inhibition activity than ethanolic extracts [108].

\section{Effects on oral and dental health:}

The antimicrobial properties of aqueous and alcoholic extracts of Eucalyptus leaves was investigated against the most cariogenic bacteria in mouth (Mutans streptococci and Lactobacilli) and against Candida albicans. There was statistically highly significant difference $(\mathrm{P}<0.001)$ between different concentrations of the aqueous and alcoholic extracts on the sensitivity of the isolates, whilst the alcoholic extract was more effective than aqueous extract just at low concentrations. At 100 and $150 \mathrm{mg} / \mathrm{ml}$ the alcoholic and the aqueous extracts showed more potent effect than $2 \mathrm{mg} / \mathrm{ml}$ chlorhexidine against Mutans streptococci and Candida albicans. Minimum bactericidal concentration for the aqueous extract was $5-8 \mathrm{mg} / \mathrm{ml}, 6-10 \mathrm{mg} / \mathrm{ml}$ and 3-7mg/ml against Mutans streptococci, Lactobacilli and Candida albicans respectively while that of alcoholic extract was 4$8 \mathrm{mg} / \mathrm{ml}, 6-10 \mathrm{mg} / \mathrm{ml}$ and $2-6 \mathrm{mg} / \mathrm{ml}$ against the same microorganisms respectively [156].The effect of chewing gum containing Eucalyptus extract on periodontal health was investigated in a double-masked, randomized, controlled trial. Healthy humans with gingivitis but not deep periodontal pockets were randomly assigned to the following groups: high-concentration group $(n=32)$ : use of $0.6 \%$ Eucalyptus extract chewing gum for 12 weeks (90 mg/day); low-concentration group $(n=32)$ : use of $0.4 \%$ Eucalyptus extract chewing gum for 12 weeks $(60$ $\mathrm{mg} /$ day); and placebo group $(\mathrm{n}=33)$ : use of chewing gum without Eucalyptus extract for the same period. Plaque accumulation (PLA), gingival index (GI), bleeding on probing (BOP), periodontal probing depth (PD), and clinical attachment level (CAL) were measured at weeks 0, 4, 8, 12, and 14. The interaction between the effects of Eucalyptus extract chewing gum and the intake period was statistically significant for PLA, GI, BOP, and $\mathrm{PD}$, but not for CAL. The low- and high-concentration groups exhibited statistically significant $(\mathrm{P}<0.05)$ improvements compared to the placebo group for PLA, GI, BOP, and PD [157].

\section{Dermatological effects:}

A long-term usage of a scalp lotion containing Eucalyptus extract, was investigated to explore the change in physical properties of the hair fiber. Half-head or whole-head usage studies of a scalp lotion with Eucalyptus extract were carried out on the following groups: Japanese female, Japanese senior female, Japanese male, and Caucasian female panelists. The improvement in hair luster and bounce in the root part of the hair were recognized by the panelists after the long-term application of the scalp lotion with Eucalyptus extract. The results indicated that the recognition of panelists was based on an actual change in the hair fiber properties. The efficacy of Eucalyptus extract was expressed regardless of race, age, or gender, since similar results were confirmed in all panelist groups. To study the mechanism, the elasticity (Young's modulus) of the new-growth part of the cortex in Eucalyptus extract-treated hair and placebo hair were evaluated by the nano-indentation method of atomic force microscopy (AFM). The results suggested that the Young's modulus of the new-growth part of the cortex in Eucalyptus extract treated-hair was increased in comparison with placebo hair. The IR spectra of treated samples of hair showed changes that appear to confirm a decrease in the alpha-helix structure and an increase in the beta-sheet structure [158].

\section{Nasal effect:}

An ex vivo cultures of human nasal turbinate slices was established to investigate the effects of 1,8 cineol on mucus hypersecretion in experimentally induced rhinosinusitis. Treatment of nasal slice cultures with lipopolysaccharides mimicking bacterial infection led to a significantly increased number of mucin-filled goblet cells. The number of mucin-filled goblet cells was found to be significantly decreased after co-treatment with 1,8-cineol. On a molecular level, real time PCR-analysis further showed that 1,8-cineol significantly reduce the expression levels of the mucin genes MUC2 and MUC19 in close association with significantly attenuated NF$\kappa B$-activity [159].

\section{Antidiabetic effect:}

The anti-hyperglycemic activity of the ethanolic extract of Eucalyptus camaldulensis leaves was studied on oral glucose tolerance test on albino rats. The administration of the ethanolic extract at a dose of 500 $\mathrm{mg} / \mathrm{kg}$ of body weight showed a highly significant reduction in blood glucose when compared with control ( $\mathrm{P}<$ $0.001)[160]$.

\section{Other effects:}

The effect of Eucalyptus essential oil mixed with milk casein peptide food was studied on physiological relaxation in human. Fifteen male university students $(21.2 \pm 0.9 \mathrm{yr})$ were participated in the study. They were given one of two types of experimental drink (peptide + Eucalyptus flavor $(P e p+E F)$, and peptide + grape fruit orange flavor $(\mathrm{Pep}+\mathrm{G} \cdot \mathrm{O})$, each flavor contains natural essential oil). The change in 
salivary cortisol concentration and profile of mood states (POMS) scores before and two hours after taking experimental drink was investigated. The concentration of salivary cortisol decreased significantly two hours after taking Pep + EF. There were no statistically significant differences in all POMS scores between before and after taking Pep + EF and Pep + G·O [161].

\section{Side effects and toxicity:}

An accidental ingestion of Eucalyptus oil by a 3-year-old boy caused profound central nervous system depression within 30 minutes, on examination he was deeply comatose and his breath smelt Eucalyptus odour. The pupils were constricted, muscle tone was markedly reduced, and his tendon reflexes could not be elicited. His respiration was shallow and irregular at a rate of $10 / \mathrm{min}$. The pulse rate was 70 beats/min and the blood pressure 75/40 $\mathrm{mmHg}$. However, he recovered rapidly after gastric lavage. 2 hours after admission his pulse, blood pressure, and respiration rate had gradually returned to normal. After 5 hours consciousness had gradually been regained, and by 24 hours physical examination was normal apart from a faint smell of Eucalyptus on the breath [162]. Callers to the Poison Information Centre reported that 251 children had ingested an essential oil or product of them, 50 children ingested Eucalyptus oil. The most common symptoms were cough, vomiting and cough associated with vomiting. Two children had seizures but recovered [163].A retrospective analysis, of infants and children admitted to the Royal Children's Hospital, Melbourne, between 1 January 1981 and 31 December 1992 with a diagnosis of Eucalyptus oil poisoning, was carried out. 109 children (mean age, 23.5 months; range, 0.5-10.7) were admitted; clinical effects were observed in 59\%. Thirty-one (28\%) had depression of conscious state; 27 were drowsy, three were unconscious after ingesting of known or estimated volumes of between 5 and $10 \mathrm{ml}$, and one was unconscious with hypoventilation after ingesting an estimated 75 $\mathrm{ml}$. Vomiting occurred in $37 \%$, ataxia in $15 \%$ and pulmonary disease in $11 \%$. In 27 patients who ingested known doses of Eucalyptus oil, 10 had nil effects after a mean of $1.7 \mathrm{~mL}, 11$ had minor poisoning after a mean of $2.0 \mathrm{ml}$, five had moderate poisoning after a mean of $2.5 \mathrm{ml}$ and one had major poisoning after $7.5 \mathrm{ml}$. No treatment was given for $12 \%$. Ipecac or oral activated charcoal was given for $21 \%$, nasogastric charcoal for $57 \%$, and gastric lavage without anaesthesia for $4 \%$ and under anaesthesia for $6 \%$. All patients were recovered [164].

\section{v. CONCLUSION:}

The current review discussed the chemical constituents of different Eucalyptus species grown in Iraq and their pharmacological and therapeutic potentials to enhance their uses in medical practice as a results of their effectiveness and safety.

\section{REFERENCES:}

[1] Al-Snafi AE. Therapeutic properties of medicinal plants: a review of their detoxification capacity and protective effects (part 1). Asian Journal of Pharmaceutical Science \& Technology 2015; 5(4): 257-270. http://www.ajpst.com/File_Folder/257-270(ajpst).pdf

[2] Al-Snafi AE. Therapeutic properties of medicinal plants: a review of plants with hypolipidemic, hemostatic, fibrinolytic and anticoagulant effects (part 1). Asian Journal of Pharmaceutical Science \& Technology 2015; 5(4): 271-284. http://www.ajpst.com/File_Folder/271-284(ajpst).pdf

[3] Al-Snafi AE. Therapeutic properties of medicinal plants: a review of their effect on reproductive systems (part 1). Ind J of Pharm Sci \& Res 2015; 5(4): 240-248.

[4] Al-Snafi AE. Therapeutic properties of medicinal plants: a review of their gastro-intestinal effects (part 1). Ind J of Pharm Sci \& Res 2015; 5(4): 220-232.

[5] Al-Snafi AE. Therapeutic properties of medicinal plants: a review of their antiparasitic, antiprotozoal, molluscicidal and insecticidal activity (part 1). J of Pharmaceutical Biology 2015; 5(3): 203-217.

[6] Al-Snafi AE. Therapeutic potential of Erodium cicutarium - A review. Indo Am J P Sci 2017; 4(02): 407413.

[7] Al-Snafi AE. Therapeutic importance of Ephedra alata and Ephedra foliata- A review. Indo Am J P Sci 2017; 4(02): 399-406.

[8] Al-Snafi AE. Pharmacological and therapeutic importance of Echium italicum- A review. Indo Am J P Sci 2017; 4(02): 394-398.

[9] Al-Snafi AE. Therapeutic properties of medicinal plants: a review of plants with antioxidant activity (part 1). International Journal of Pharmacology and Toxicology 2015; 6(3): 159-182.

[10] Al-Snafi AE. Therapeutic properties of medicinal plants: a review of their respiratory effects ( part 1). International Journal of Pharmacological Screening Methods 2015; 5(2):64-71.

[11] Al-Snafi AE. Therapeutic properties of medicinal plants: a review of their antiviral activity (part 1). International Journal of Pharmacological Screening Methods 2015; 5(2): 72-79.

[12] Al-Snafi AE. Pharmacology and therapeutic potential of Euphorbia hirta (Syn: Euphorbia pilulifera) A review. IOSR Journal of Pharmacy 2017; 7(3): 7-20. 
[13] Al-Snafi AE. A review on Fagopyrum esculentum: A potential medicinal plant. IOSR Journal of Pharmacy 2017; 7(3): 21-32.

[14] Al-Snafi AE. Nutritional and pharmacological importance of Ficus carica - A review. IOSR Journal of Pharmacy 2017; 7(3): 33-48.

[15] Al-Snafi AE. Medicinal plants possessed anti-inflammatory antipyretic and analgesic activities (part 2)plant based review. Sch Acad J Pharm 2016; 5(5): 142-158. http://saspublisher.com/wpcontent/uploads/2016/06/SAJP-55142-158.pdf

[16] Al-Snafi AE. Medicinal plants affected reproductive systems (part 2) - plant based review. Sch Acad J Pharm 2016; 5(5): 159-174. http://saspublisher.com/wp-content/uploads/2016/06/SAJP-55159-174.pdf

[17] Al-Snafi AE. Medicinal plants with anticancer effects (part 2)- plant based review. Sch Acad J Pharm 2016; 5(5): 175-193. http://saspublisher.com/wp-content/uploads/2016/06/SAJP-55175-193.pdf

[18] Al-Snafi AE. Antiparasitic, antiprotozoal, molluscicidal and insecticidal activity of medicinal plants (part 2) - plant based review. Sch Acad J Pharm 2016; 5(6): 194-207.

[19] Al-Snafi AE. Medicinal plants with antidiabetic effects (part 2): plant based review. IOSR Journal of Pharmacy 2016; 6(7): 49-61. http://www.iosrphr.org/papers/v6i7V2/F06724961.pdf

[20] Al-Snafi AE. Medicinal plants with antioxidant and free radical scavenging effects (part 2): plant based review. IOSR Journal Of Pharmacy 2016; 6(7): 62-82.

[21] Al-Snafi AE. Medicinal plants with antimicrobial activities (part 2): Plant based review. Sch Acad J Pharm 2016; 5(6): 208-239. http://saspublisher.com/wp-content/uploads/2016/07/SAJP-56208-239.pdf

[22] Al-Snafi AE. Medicinal plants with cardiovascular effects (part 2): plant based review. IOSR Journal of Pharmacy 2016; 6(7): 43-62. http://www.iosrphr.org/papers/v6i7V3/E067034362.pdf

[23] Al-Snafi AE. Detoxification capacity and protective effects of medicinal plants (part 2): plant based $\begin{array}{llllll}\text { review. IOSR Journal of } & \text { 63-84. }\end{array}$ http://www.iosrphr.org/papers/v6i7V3/F067036384.pdf

[24] Al-Snafi AE. Beneficial medicinal plants in digestive system disorders (part 2): plant based review. IOSR Journal of Pharmacy 2016; 6(7): 85-92. http://www.iosrphr.org/papers/v6i7V3/G067038592.pdf

[25] Al-Snafi AE. Antimicrobial effects of medicinal plants (part 3): plant based review. IOSR Journal of Pharmacy 2016; 6(10): 67-92. http://www.iosrphr.org/papers/v6i10V3/I0610036792.pdf.

[26] Al-Snafi AE. The contents and pharmacological importance of Corchorus capsularis- A review. IOSR Journal of Pharmacy 2016; 6(6): 58-63. http://www.iosrphr.org/papers/v6i6V3/F06635863.pdf

[27] Al-Snafi AE. The chemical constituents and pharmacological effects of Convolvulus arvensis and Convolvulus scammonia- A review. IOSR Journal of Pharmacy 2016; 6(6): 64-75. http://www.iosrphr.org/papers/v6i6V3/G06636475.pdf

[28] Al-Snafi AE. A review on chemical constituents and pharmacological activities of Coriandrum sativum. IOSR Journal of Pharmacy 2016; 6(7): 17-42. http://www.iosrphr.org/papers/v6i7V3/D067031742.pdf

[29] Al-Snafi AE. Pharmacology and toxicology of Conium maculatum- A review. The Pharmaceutical and Chemical Journal 2016; 3(2):136-142. http://tpcj.org/download/vol-3-iss-2-2016/TPCJ2016-03-02-136142.pdf

[30] Al-Snafi AE. The constituents and pharmacology of Cnicus benedictus- A review. The Pharmaceutical and Chemical Journal 2016; 3(2):129-135. http://tpcj.org/download/vol-3-iss-2-2016/TPCJ2016-03-02129-135.pdf

[31] Al-Snafi AE. Medicinal importance of Colchicum candidum- A review. The Pharmaceutical and Chemical Journal 2016; 3(2):111-117. http://tpcj.org/download/vol-3-iss-2-2016/TPCJ2016-03-02-111117.pdf

[32] Al-Snafi AE. Nutritional value and pharmacological importance of citrus species grown in Iraq. IOSR Journal of Pharmacy 2016; 6(8): 76-108. http://www.iosrphr.org/papers/v6i8V1/H0680176108.pdf

[33] Al-Snafi AE. The pharmacological and toxicological effects of Coronilla varia and Coronilla scorpioides: A review. The Pharmaceutical and Chemical Journal 2016; 3(2): 105-114. http://tpcj.org/download/vol-3-iss-3-2016/TPCJ2016-03-03-105-114.pdf

[34] Al-Snafi AE. Pharmacological activities of Cotoneaster racemiflorus- A review. The Pharmaceutical and Chemical Journal 2016, 3(2):98-104. http://tpcj.org/download/vol-3-iss-3-2016/TPCJ2016-03-03-98104.pdf

[35] Al-Snafi AE. The constituents and pharmacology of Corchorus aestuans: A review. The Pharmaceutical and Chemical Journal 2016; 3(4):208-214. http://tpcj.org/download/vol-3-iss-4-2016/TPCJ2016-03-04208-214.pdf

[36] Al-Snafi AE. The chemical constituents and pharmacological activities of Cymbopagon schoenanthus: A review. Chemistry Research Journal 2016; 1(5):53-61. http://chemrj.org/download/vol-1-iss-52016/chemrj-2016-01-05-53-61.pdf 
[37] Al-Snafi AE. Traditional uses, constituents and pharmacological effects of Cuscuta planiflora. The Pharmaceutical and Chemical Journal 2016; 3(4): 215-219. http://tpcj.org/download/vol-3-iss-42016/TPCJ2016-03-04-215-219.pdf

[38] Al-Snafi AE. A review on Dodonaea viscosa: A potential medicinal plant. IOSR Journal of Pharmacy 2017; 7(2): 10-21. http://www.iosrphr.org/papers/v7i2V1/B0702011021.pdf

[39] Al-Snafi AE. The pharmacology and medical importance of Dolichos lablab (Lablab purpureus)- A review. IOSR JOurnal of Pharmacy2017; $\quad$ 22-30. http://www.iosrphr.org/papers/v7i2V1/C0702012230.pdf

[40] Al-Snafi AE. Pharmacological and therapeutic importance of Desmostachya bipinnata- A review. Indo Am J P Sci 2017; 4(01): 60-66. http://iajps.com/pdf/january2017/9.Ali\%20Esmail\%20AlSnafi,IAJPS\%202017,4\%20(01),60-66.pdf

[41] Al-Snafi AE. Chemical constituents and pharmacological effects of Eryngium creticum- A review. Indo Am J P Sci 2017; 4(01): 67-73. http://iajps.com/pdf/january2017/10.\%20Ali\%20Esmail\%20AlSnafi,IAJPS\%202017,\%20(01),\%2067-73.pdf

[42] Al-Snafi AE. The pharmacology of Equisetum arvense- A review. IOSR Journal of Pharmacy 2017; 7(2): 31-42. http://www.iosrphr.org/papers/v7i2V1/D0702013142.pdf

[43] Al-Snafi AE. A review on Erodium cicutarium: A potential medicinal plant. Indo Am J P Sci 2017; 4(01): 110-116.

[44] Al-Snafi AE. Pharmacology of Echinochloa crus-galli - A review. Indo Am J P Sci 2017; 4(01): 117122.

[45] Al-Snafi AE. The pharmacological potential of Dactyloctenium aegyptium- A review. Indo Am J P Sci 2017; 4(01): 153-159.

[46] Al-Snafi AE. Chemical constituents, pharmacological and therapeutic effects of Eupatorium cannabinum- A review. Indo Am J P Sci 2017; 4(01): 160-168.

[47] Al-Snafi AE. Nutritional and therapeutic importance of Daucus carota- A review. IOSR Journal of Pharmacy 2017; 7(2): 72-88.

[48] Al-Snafi AE. Chemical constituents and pharmacological effects of Dalbergia sissoo - A review. IOSR Journal of Pharmacy 2017; 7(2): 59-71.

[49] Al-Snafi AE. Medical importance of Datura fastuosa (syn: Datura metel) and Datura stramonium - A review. IOSR Journal of Pharmacy 2017; 7(2):43-58.

[50] Al-Snafi AE. A review on Dodonaea viscosa: A potential medicinal plant. IOSR Journal of Pharmacy 2017; 7(2): 10-21.

[51] Al-Rawi A and Chakravarty HL, Medicinal plants of Iraq, Ministry of Agriculture and Technology, Bulletin No: 146, Baghdad, Iraq 1964.

[52] Jasim AMN. Study some of constituents of Eucalyptus leaves, and the effects of its extracts on microorganism. Al-Mustansiriyah Journal of Science 2005; 2(16): 62-71.

[53] Saleh TA, Abid TM and Thaker AA. The accumulative and non accumulative effects of water and some organic extracts of Eucalyptus microtheca and Datura innoxia on the larvae of Culex quinquefasciatus. Anbar J Agriculture Sciences 2010; 8(4): 321-333.

[54] Suliman KD and Al-Dulimi FI. The synergestic inhibitory effect Ulmus rubra and Eucalyptus microtheca against Staphylococcus aureus and Salmonella typhimurium isolated from food poisoning. Journal of Education and Science 2008; 21(3): 28-52.

[55] The plant list, a working list of all plant species, Eucalyptus bicolor, http://www. theplantlist.org/tpl/record/kew-72526

[56] Global biodiversity information facility, Synonyms for "Eucalyptus camaldulensis", http://www.gbif.org/species/3176197/synonyms

[57] The plant list, a working list of all plant species, Eucalyptus griffithsii http://www. theplantlist.org/tpl/record/kew-73052

[58] The plant list, a working list of all plant species, Eucalyptus incrassata, http://www. theplantlist.org/tpl/record/kew-73123

[59] The plant list, a working list of all plant species, Eucalyptus microtheca, http://www. theplantlist.org/tpl/record/kew-73380

[60] Firewood Crops: Shrub and Tree Species for Energy Production. National Academy Press, Washington, D.C. $1983: 132$

[61] U.S. National Plant Germplasm System, Eucalyptus rostrata, https://npgsweb. arsgrin.gov/gringlobal/taxonomydetail.aspx?id=16017

[62] ITIS report, http://www.itis.gov/servlet/SingleRpt/SingleRpt?search_topic $=$ TSN\& search_value=27189

[63] U.S. National Plant Germplasm System, https://npgsweb. ars-grin.gov/gringlobal/ taxonomydetail.aspx?15867 
[64] CIMMYT-Maize Germplasm Bank 1.9.4, http://mgb. cimmyt.org/gringlobal/ taxonomydetail.aspx id $=401197$

[65] U.S. National Plant Germplasm System, Eucalyptus torquata, https://npgsweb.arsgrin.gov/gringlobal/taxonomydetail.aspx?16046

[66] El-Sayed FRS. A pharmacognostical study of Eucalyptus cinerea cultivated in Egypt. MSc thesis, Faculty of Pharmacy, Cairo University 2012.

[67] Sastri BN. The Wealth of India. A dictionary of Indiar materials and industrial products. Raw Materials, Vol V. Council of Scientific and Industrial Research. New Delhi 2002: 203-204.

[68] PlantNet, Eucalyptus largiflorens F. Muell., http://plantnet.rbgsyd.nsw.gov.au/cgibin/NSWfl.pl?page=nswfl\&lvl=sp\&name=Eucalyptus $\sim$ largiflorens

[69] Paddock Plants, Black box, www.dpi.nsw.gov.au/legal [ 9 Nov 2010].

[70] Orwa C, Mutua C, Kindt R and Jamnadass R, S Anthony. 2009. Agroforestree Database: a tree $\begin{array}{lllll}\text { reference and } & \text { gelection } & & & \text { http://www. }\end{array}$ worldagroforestry.org/sites/treedbs/treedatabases.asp

[71] Little ELJr. Common fuelwood crops: a handbook for their identification. McClain Printing Co., Parsons, WV 1983.

[72] EucaLink, A Web Guide to the Eucalypts, Eucalyptus griffithsii, http://plantnet. rbgsyd.nsw.gov.au/cgibin/euctax.pl?/PlantNet/Euc=\&name= Eucalyptus+griffithsii

[73] FloraBase, Eucalyptus griffithsii Maiden Griffith's Grey Gum, https://florabase. dpaw.wa.gov.au/browse/profile/5665

[74] EucaLink, A Web Guide to the Eucalypts, Eucalyptus costata, http://plantnet.rbgsyd.nsw.gov.au/cgi-bin/ euctax. pl?/ PlantNet /Euc= \&name= Eucalyptus +costata

[75] Department of Parks and wildlife, Western Australian herbarium, Eucalyptus incrassata Labill. Lerp Mallee, https://florabase.dpaw.wa.gov.au/ browse/profile/5675

[76] EucaLink, A web guide to the Eucalypts, Eucalyptus microtheca, http://plantnet. rbgsyd.nsw.gov.au/cgibin/euctax.pl?/PlantNet/Euc=\&name=Eucalyptus+microtheca

[77] Trees, Eucalyptus coolabahs, http://archive.lls.nsw.gov.au/_data/assets/pdf_file /0009/ 495801/archivetrees.pdf

[78] Australian Native Plants, Eucalyptus torquata, http://anpsa.org.au/e-tor.html

[79] WHO monographs on selected medicinal plants. Vol 2. World Health Organization. Geneva 2002: 106113.

[80] African pharmacopoeia. Vol 1, $1^{\text {st }}$ ed. Lagos, Organization of African Unity, Scientific, Technical \& Research Commission 1985.

[81] Blumenthal M et al.(eds). The complete German Commission E monographs. Austin,TX, American Botanical Council 1998.

[82] Assessment report on Eucalytus globulus Labill., Eucalyptus polybractea R. T. Baker and/or Eucalyptus

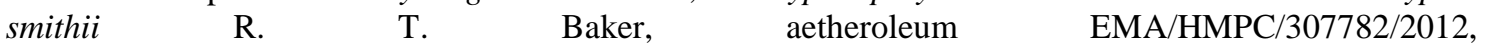
http://www.ema.europa.eu/docs/en_GB/document_library/Herbal_-_HMPC_ assessment_report/2014/05/WC500166508.pdf

[83] Blaschek W, Ebel S, Hilgenfeldt U, Holzgrabe U, Keller K, Reichling J and Schulz V (editors). Hagers Enzyklopädie der Arzneistoffe und Drogen. Eucalyptus. Wissenschaftliche Verlagsgesellschaft $\mathrm{mbH}$, Stuttgart 2007.

[84] Pearson M. The good oil: Eucalyptus oil distilleries in Australia. Australian Historical Archaeology 1993; 11: 99-107.

[85] PDR for Herbal Medicine, $1^{\text {st }}$ ed. Medical Economics Company 1998: 283.

[86] Baranska M, Schulz H, Reitzenstein S, Uhlemann U, Strehle MA, Krüger H, Quilitzsch R, Foley W and Popp J. Vibrational spectroscopic studies to acquire a quality control method of Eucalyptus essential oils. Biopolymers 2005; 78:237-248.

[87] Silvestre AJD, Cavaleiro JAS, Delmond B, Filliatre C and Burgeois G. Analysis of the variation of essential oil composition of Eucalyptus globulus Labill from Portugal using multivariate statistical analysis. Ind Crop Pro 1997; 6:27-33

[88] Wichtl M. Teedrogen und Phytopharmaka $3^{\text {rd }}$ ed. Eucalyptus leaf. Wissenschaftliche Verlagsgesellschaft mbH, Stuttgart 2004.

[89] Betts TJ. Solid phase microextraction of volatile constituents from individual fresh Eucalyptus leaves of three species. Planta Med 2000; 66:193-195

[90] Daroui-Mokaddem H, Kabouche A, Bouacha M, Soumati B, El-Azzouny A, Bruneau C and Kabouche Z. GC/MS analysis and antimicrobial activity of essential oil and fresh leaves of Eucalyptus globulus, and leaves and stems of Smyrnium olusatrum from Constantine (Algeria). Nat Prod Commun 2010; 5: 16691672. 
[91] Croteau R. Biosynthesis and catabolism of monoterpenoids. Chem Rev 1987; 87: 929-954.

[92] Croteau R, Alonso WR, Koepp AE and Johnson MA. Biosynthesis of monoterpenes: partial purification, characterization, and mechanism of action of 1,8-cineole synthase. Arch Biochem Biophys 1994; 309: 184-192.

[93] Moore BD, Wallis IR, Palá-Paul J, Brophy JJ, Willis RH and Foley WJ. Antiherbivore chemistry of Eucalyptus-cues and deterrents for marsupial folivores. J Chem Ecol 2004; 30(9): 1743-1769.

[94] Brophy JJ and Southwell IA. Eucalyptus chemistry 2002: 102-160. In JJW Coppen (ed.). Eucalyptus: The Genus Eucalyptus. Taylor \& Francis, London and New York 2002.

[95] Sefidkon F, Assareh MH, Abravesh Z and Barazandeh MM. Chemical composition of the essential oils of four cultivated Eucalyptus species in Iran as medicinal plants (E. microtheca, E. spathulata, E. largiflorens and E. torquata). Iranian Journal of Pharmaceutical Research 2007; 6(2), 135-140.

[96] Sani I, Abdulhamid A and Bello F. Eucalyptus camaldulensis: Phytochemical composition of ethanolic and aqueous extracts of the leaves, stem-bark, root, fruits and seeds. Journal of Scientific and Innovative Research 2014; 3(5): 523-526.

[97] Huang HC, Ho YC, Lim JM, Chang TY, Ho CL and Chang TM. Investigation of the antimmelanogenic and antioxidant characteristics of Eucalyptus camaldulensis flower essential oil and determination of its chemical composition. Int J Mol Sci 2015; 16: 10470-10490.

[98] Barra A, Coroneo V, Dessi S, Cabras P and Angioni A. Chemical variability, antifungal and antioxidant activity of Eucalyptus camaldulensis essential oil from Sardinia. Nat Prod Commun 2010; 5(2): 329-335.

[99] Ashraf M, Ali Q, Anwar F and Jussain AI. Composition of leaf essential oil of Eucalyptus camaldulensis. Asian Journal of Chemistry 2010; 22(3): 1779-1786.

[100] Begum S,Sultana I, Siddiqui BS, Shaheen F and Gilani AH. Structure and apasmolytic activity of eucalyptanoic acid from Eucalyptus camaldulensis var. obtusa and synthesis of its active derivative from oleanolic acid. J Nat Prod 2002; 65 (12): 1939-1941.

[101] Begum S, Sultana I, Siddiqui BS, Shaheen F and Gilani AH. Spasmolytic constituents from Eucalyptus camaldulensis var. obtuse leaves. J Nat Prod 2000; 63 (9): 1265-1268.

[102] Siddiqui BS, Sultana I and Begum S. Triterpenoidal constituents from Eucalyptus camaldulensis var. obtusa leaves. Phytochemistry 2000; 54(8): 861-865.

[103] Singab A, Ayoub N, Al-Sayed E, Martiskainen O, Sinkkonen J and Pihlaja K. Phenolic constituents of Eucalyptus camaldulensis Dehnh, with potential antioxidant and cytotoxic activities. Records of Natural Products 2011; 5(4): 271-280

[104] Salman ED, AL-Saedi AJH, AL-Kazzaz AGhM and Yahya SS. The effect of aqueous extract and essential oils of the leaves of Eucalyptus incrassate on $\beta$ - lactam resistant Staphylococcus aureus. Ibn Al-Haitham J for Pure \& Appl Sci 2014; 17(1): 76-82.

[105] Bignell CM, Dunlop PJ, Brophy JJ and Jackson JF. Volatile leaf oils of some south-western and southern Australian species of the genus Eucalyptus. Part I. Subgenus Symphyomyrtus, Section Dumaria, Series Incrassatae. Flavour and Fragrance J 1994; 9(3):113-117.

[106] Eucalyptus incrassate, Health effects and herbal facts, http://www.naturalmedicine facts. info/plant/eucalyptus-incrassata.html\#null

[107] Takasaki M, Konoshima T, Kozuka M, Haruna M, Ito K, Crow WD and Paton DM. Euglobal-In-1, a new euglobal from Eucalyptus incrassata. Chem Pharm Bull (Tokyo) 1994; 42(10): 2113-2116.

[108] Mahmoud SN. Antifungal activity of Cinnamomum zeylanicum and Eucalyptus microtheca crude extracts against food spoilage fungi. Euphrates Journal of Agriculture Science 2012; 4 (3): 26-39.

[109] Maghsoodlou MT, Kazemipoor N, Valizadeh J, Seifi MFN and Rahneshan N. Essential oil composition of Eucalyptus microtheca and Eucalyptus viminalis. Avicenna J Phytomed 2015; 5(6): 540-552.

[110] Pino JA, Marbot R, Quert, R and Garcia H. Study of essential oils of Eucalyptus resinifera, E. tereticornis and Corymbia maculata (Hook.) grown in Cuba. Flavour Frag J 2002; 17: 1-14.

[111] Coppen JJW and Hone GA. Eucalyptus oils: a review of production and markets (NRI Bulletin 56). Universty of Greenwich, Natural resources institute 1992: 8.

[112] Lawal TO, Adeniyi BA and Olaleye SB. Ulcer-healing promoting activities of methanol extracts of Eucalyptus camaldulensis Dehnh. and Eucalyptus torelliana F. Muell in rat. A rch Bas App Med 2014; 2: $147-152$.

[113] Adeniyi CB, Lawal TO and Mahady GB. In vitro susceptibility of Helicobacter pylori to extracts of Eucalyptus camaldulensis and Eucalyptus torelliana. Pharm Biol 2009; 47(1):99-102.

[114] Santos FA and Rao VS. Antiinflammatory and antinociceptive effects of 1,8-cineole a terpenoid oxide present in many plant essential oils. Phytother Res 2000; 14(4): 240-244.

[115] Juergens UR, Stöber M, Schmidt-Schilling L, Kleuver T and Vetter H. Antiinflammatory effects of euclyptol (1.8-cineole) in bronchial asthma: inhibition of arachidonic acid metabolism in human blood monocytes ex vivo Eur J Med Res 1998; 3(9): 407-412. 
[116] Juergensa UR, Engelena T, Rackéb K, Stöbera M, Gillissenc A and Vettera H. Inhibitory activity of 1,8-cineol (eucalyptol) on cytokine production in cultured human lymphocytes and monocytes. Pulmonary Pharmacology \& Therapeutics 2004; 17(5): 281-287.

[117] Serafino A, Vallebona PS, Andreola F, Zonfrillo M, Mercuri L, Federici M, Rasi G, Garaci E and Pierimarchi P. Stimulatory effect of Eucalyptus essential oil on innate cell-mediated immune response. BMC Immunol 2008; 9: 17.

[118] Juergens UR, Stöber M and Vetter H. Inhibition of cytokine production and arachidonic acid metabolism by eucalyptol (1.8-cineole) in human blood monocytes in vitro. Eur J Med Res 1998; 3(11): 508-510.

[119] Liapi C, Anifandis G, Chinou I, Kourounakis AP, Theodosopoulos S and Galanopoulou P. Antinociceptive properties of 1,8-Cineole and beta-pinene, from the essential oil of Eucalyptus camaldulensis leaves, in rodents. Planta Med 2007; 73(12): 1247-1254.

[120] Atta AH and Alkofahi A. Anti-nociceptive and anti-inflammatory effects of some Jordanian medicinal plant extracts. J Ethnopharmacol 1998; 60(2):117-124.

[121] Moon HK, Kang P, Lee HS, Min SS and Seol GH. Effects of 1,8-cineole on hypertension induced by chronic exposure to nicotine in rats. J Pharm Pharmacol 2014; 66(5):688-693.

[122] Safaei-Ghomi J, Abbasi-Ahd A, Behpour M and Batooli H. Antioxidant activity of the essential oil and methanolic extract of Eucalyptus largiflorens and Eucalyptus intertexta from central Iran. Jeobp 2010; 13 (3): $377-384$.

[123] Rahimi-Nasrabadi M, Nazarian S, Farahani H, Koohbijari GRF, Ahmadi F and Batooli H. Chemical composition, antioxidant, and antibacterial activities of the essential oil and methanol extracts of Eucalyptus largiflorens F. Muell. International Journal of Food Properties 2013; 16(2): 369-381.

[124] Ghaffar A, Yameen M, Kiran S, Kamal S, Jalal F, Munir B, Saleem S, Rafiq N, Ahmad A, Saba I and Jabbar A. Chemical composition and in vitro evaluation of the antimicrobial and antioxidant activities of essential oils extracted from seven Eucalyptus species. Molecules 2015; 20: 20487-20498.

[125] El-Baz FK, Mahmoud Kh, El-Hallouty SM, El-Kinawy OS and Ali SI. Antioxidant, antiproliferated activities and GC/MS analysis of Eucalyptus camaldulensis essential oil. Int J Pharm Bio Sci 2015; 6(2): (B) $883-892$.

[126] El-Ghorab AH, El-Massry KF, Marx F and Fadel HM. Antioxidant activity of Egyptian Eucalyptus camaldulensis var. brevirostris leaf extracts. Nahrung 2003; 47(1): 41-45.

[127] Salem MZ, Ashmawy NA, Elansary HO and El-Settawy AA. Chemotyping of diverse Eucalyptus species grown in Egypt and antioxidant and antibacterial activities of its respective essential oils. Nat Prod Res 2015;29(7):681-685.

[128] Murata S, Shiragami R, Kosugi C et al. Antitumor effect of 1, 8-cineole against colon cancer. Onchology Report 2013: 2647-2652.

[129] Al-Fatimi M, Friedrich U and Jenett-Siems K. Cytotoxicity of plants used in traditional medicine in Yemen. Fitoterapia 2005; 76(3-4):355-358.

[130] Mubarak EE, Zeenelabdin Ali L, Ahmed IFA, Ahmed ABA and Taha RM. Essential oil compositions and cytotoxicity from various organs of Eucalyptus camaldulensis. Int J Agric Biol 2015; 17: 320-326.

[131] Jelena D et al. Myrtus communis and Eucalyptus camaldulensis cytotoxicity on breast cancer cells. Proc Nat Sci Matica Srpska Novi Sad 2012; 123: 65-73.

[132] Islam F, Khanam JA, Khatun M, Zuberi N, Khatun L, Kabir, Md Abu Reza SR, Ali MM, Rabbi MA, Gopalan V and Lam AKY. A p-Menth-1-ene-4,7-diol (EC-1) from Eucalyptus camaldulensis Dhnh. Triggers apoptosis and cell cycle changes in Ehrlich ascites carcinoma cells. Phytotherapy Research 2015; 29(4): 573-581.

[133] Adeniyi BA, Ayepola OO and Adu FD. The antiviral activity of leaves of Eucalyptus camaldulensis (Dehn) and Eucalyptus torelliana (R. Muell). Pak J Pharm Sci 2015; 28(5):1773-1776.

[134] Islam F, Khatun H, Khatun M, Ali SM and Khanam JA. Growth inhibition and apoptosis of Ehrlich ascites carcinoma cells by the methanol extract of Eucalyptus camaldulensis. Pharm Biol 2014;52(3):281-290.

[135] El-Baz FK, Mahmoud K, El-Senousy WM, Darwesh OM and ElGohary AE. Antiviral - antimicrobial and schistosomicidal activities of Eucalyptus camaldulensis essential oils. Int J Pharm Sci Rev Res 2015; 31(1): 262-268.

[136] Kabiru YA, Ogbadoyi EO, Okogun JI, Gbodi TA and Makun HA. Anti-trypanosomal potential of Eucalyptus camaldulensis. British Journal of Pharmacology and Toxicology 2013; 4(2): 25-32.

[137] Nosratabadi SJ, Sharifi I, Sharififar F, Bamorovat M, Daneshvar H and Mirzaie M. In vitro antileishmanial activity of methanolic and aqueous extracts of Eucalyptus camaldulensis against Leishmania major. J Parasit Dis 2015; 39(1): 18-21. 
[138] Hassani S, Asghari G, Yousefi H, Kazemian A, Rafieiean M and Darani HY. Effects of different extracts of Eucalyptus camaldulensis on Trichomonas vaginalis parasite in culture medium. Adv Biomed Res 2013; 2: 47.

[139] Batisha DR, Singhb HB, Kohlia RK and Kaura S. Eucalyptus essential oil as a natural pesticide. Forest Ecology and Management 2008; 256 (12): 2166-2174.

[140] Sedaghat M M, SaneiAli R, Khnavi M, Abai Mohammad R, Hadjiakhoondi A, Mohtarami F and Vatandoost H. Phytochemistry and larvicidal activity of Eucalyptus camaldulensis against malaria vector, Anopheles stephensi. Asian Pacific Journal of Tropical Medicine 2010; 3(1): 841-845.

[141] Lucia A, Licastro S, Zerba E, Gonzalez Audino P and Masuh H. Sensitivity of Aedes aegypti adults (Diptera: Culicidae) to the vapors of Eucalyptus essential oils. Bioresour Technol 2009; 100(23):60836087.

[142] Cheng SS, Huang CG, Chen YJ, Yu JJ, Chen WJ and Chang ST. Chemical compositions and larvicidal activities of leaf essential oils from two Eucalyptus species. Bioresour Technol 2009; 100(1): 452-456.

[143] Erler F, Ulug I and Yalcinkaya B. Repellent activity of five essential oils against Culex pipiens. Fitoterapia 2006;77(7-8):491-494.

[144] Tysyar AA. The effect of hot and cold water extracteous of Eucalyptus microtheca on some surviral of the mosquito Culex pipiens L. (Diptera: Culicidae) at different stages. Journal of Al-Qadisiyah for Pure Science 1997; 15(3):1-5.

[145] Trivedi NA and Hotchandani SC. A study of the antimicrobial activity of oil of Eucalyptus. Indian J Pharmacol 2004; 36(2): 93-95.

[146] Safaei-Ghomi J and Ahd AA. Antimicrobial and antifungal properties of the essential oil and methanol extracts of Eucalyptus largiflorens and Eucalyptus intertexta. Pharmacogn Mag 2010; 6(23): 172-175.

[147] Pandey B and Singh S. Evaluation of antimicrobial potential of Eucalyptus camaldulensis L. J Pharm Chem Biol Sci 2014; 2(3):166-171.

[148] El-Mahmood MA. Antibacterial potential of crude leaf extracts of Eucalyptus camaldulensis against some pathogenic bacteria. African Journal of Plant Science 2010; 4(6): 202-209.

[149] Rasooli I, Shayegh S and Astaneh S. The effect of Mentha spicata and Eucalyptus camaldulensis essential oils on dental biofilm. Int J Dent Hyg 2009; 7(3):196-203.

[150] Knezevic P, Aleksic V, Simin N, Svircev E, Petrovic A and Mimica-Dukic N. Antimicrobial activity of Eucalyptus camaldulensis essential oils and their interactions with conventional antimicrobial agents against multi-drug resistant Acinetobacter baumannii. J Ethnopharmacol 2016; 178:125-136.

[151] Bachir RG and Benali M. Antibacterial activity of essential oil of north west Algerian Eucalyptus camaldulensis against Escherichia coli and Staphylococcus aureus. Journal of Coastal Life Medicine 2014; 2(10): 799-804.

[152] Lawal TO, Adeniyi BA, Adegoke AO, Franzblau SG and Mahady GB. In vitro susceptibility of Mycobacterium tuberculosis to extracts of Eucalyptus camaldulensis and Eucalyptus torelliana and isolated compounds. Pharm Biol 2012; 50(1): 92-98.

[153] Falahati M, Tabrizib NO and Jahaniani. Anti dermatophyte activities of Eucalyptus camaldulensis in comparison with griseofulvin. Iranian Journal of Pharmacology \& Therapeutics 2005; 4(2): 80-83.

[154] Al-Jeboury GH. In vitro antibacterial activity of Eucalyptus microtheca and Cinnamomum zeylanicum crude extracts against Pseudomonas aeruginosa isolates. Medical Journal of Babylon 2013; 10(4):784793.

[155] Seyyednejad SM, Motamedi H, Najvani FD and Hassannejad Z. Antibacterial effect of Eucalyptus microtheca. Int J Enteric Pathog 2014; 2(2): 1-5.

[156] Qanbar FH and Al-Mizraqchi AS. The antimicrobial effect of aqueous \& alcoholic extracts of Eucalyptus leaves on oral Mutans streptococci, Lactobacilli \& Candida albicans (an in vitro study. J Bagh Coll Dentistry 2009; 21(4): 109-112.

[157] Nagata H, Inagaki Y, Tanaka M, Ojima M, Kataoka K, Kuboniwa M, Nishida N, Shimizu K, Osawa K and Shizukuishi S. Effect of Eucalyptus extract chewing gum on periodontal health: a double-masked, randomized trial. J Periodontol 2008; 79(8): 1378-1385.

[158] Mamada A, Ishihama M, Fukuda R and Inoue S. Changes in hair properties by Eucalyptus extract. J Cosmet Sci 2008; 59(6):481-496.

[159] Sudhoff H, Klenke C, Greiner JF, Müller J, Brotzmann V, Ebmeyer J, Kaltschmidt B and Kaltschmidt C. 1,8-Cineol reduces mucus-production in a novel human ex vivo model of late rhinosinusitis. PLoS One 2015; 10(7): e0133040.

[160] Dawoud ADH. Effects of ethanolic leaf extract of Eucalyptus camaldulensis on oral glucose tolerance test in type-2 model diabetic rats. Journal of Network Communications and Emerging Technologies (JNCET) 2015; 2(2): 6-8. 
[161] Bum-Jin P, Morikawa T, Ogata T, Washida K, Iwamoto M, Nakamura H and Miyazaki Y. Physiological effects of ingesting Eucalyptus essential oil with milk casein peptide. Silva Fennica 2009; 43(1): 173-179.

[162] Patel S and Wiggins J. Eucalyptus oil poisoning. Arch Dis Child 1980; 55: 405-406.

[163] Flaman Z, Pellechia-Clarke S, Bailey B and McGuigan M. Unintentional exposure of young children to camphor and Eucalyptus oils. Paediatr Child Health 2001; 6(2): 80-83.

[164] Tibballs J. Clinical effects and management of Eucalyptus oil ingestion in infants and young children. Med J Aust 1995; 163(4): 177-180. 